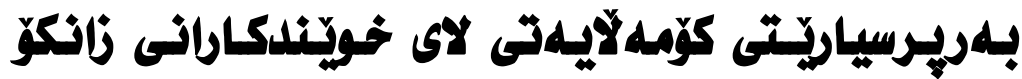

تويزينهوهيلهى ملهيلانيه، له زانكوّى سليّمانى ئلزنجامدراوه.

شنوّ حسن عبدالصملد

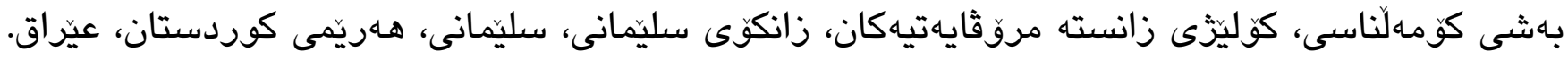

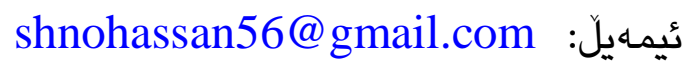

\section{يلهيمان عبدالقادر مجيد}

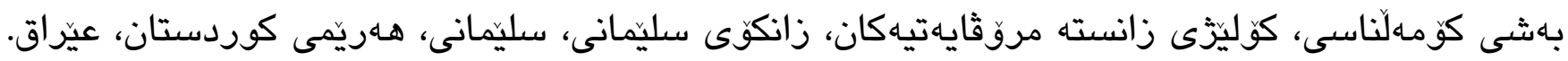
Paiman.majid@univsul.edu.iq بيمهيل

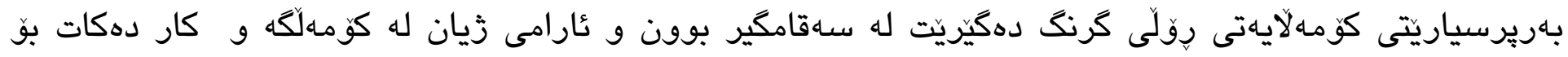

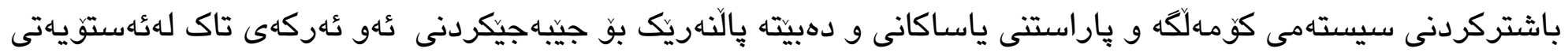

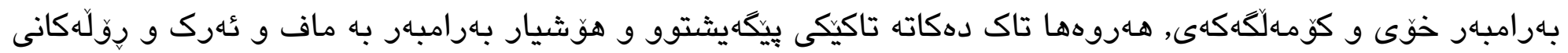

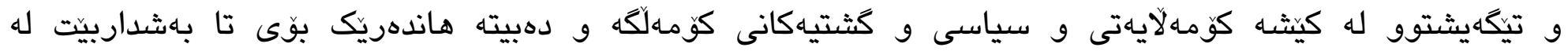

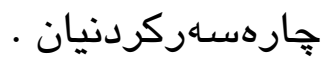

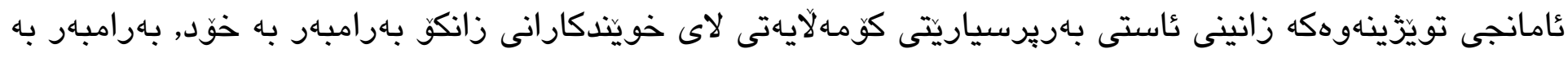

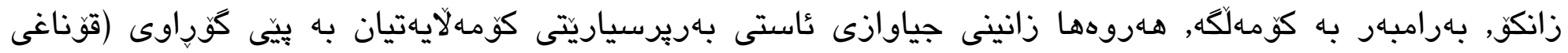

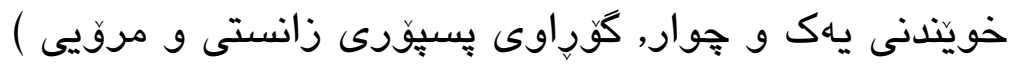

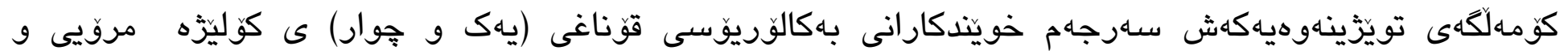

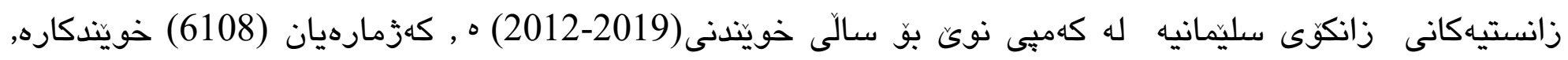

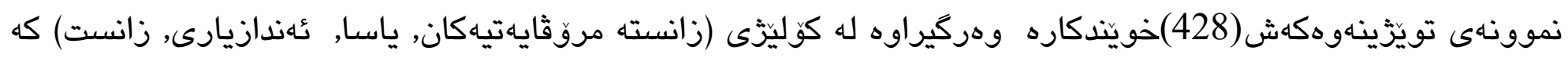




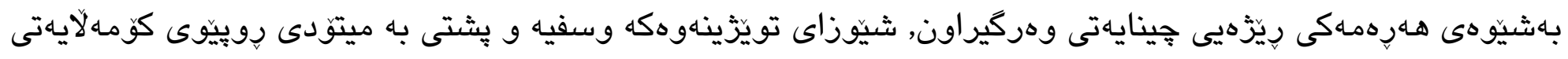

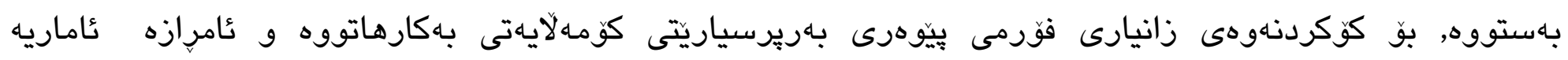

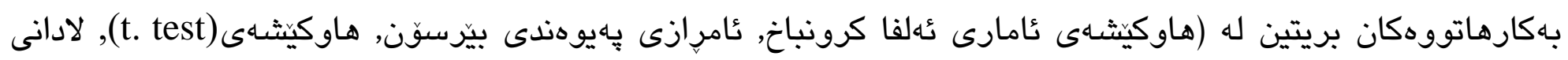

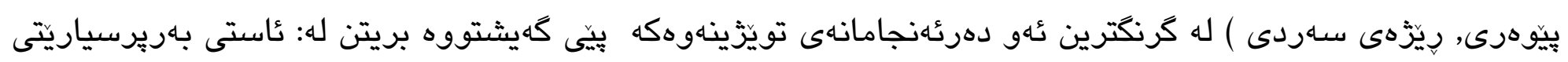

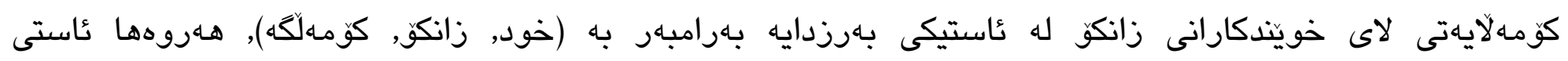

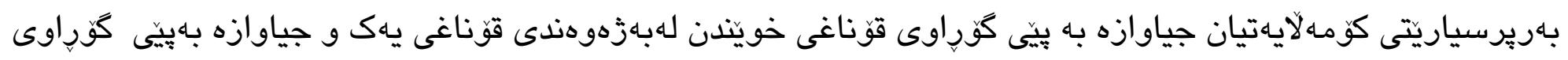

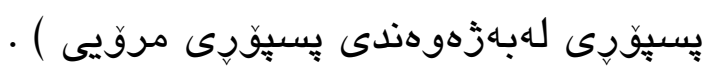

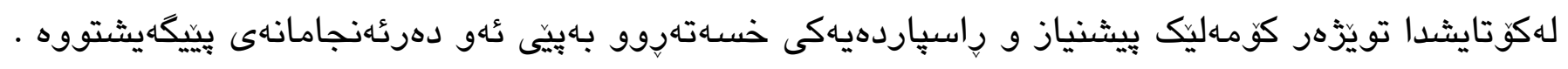

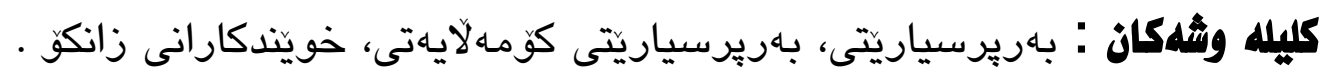

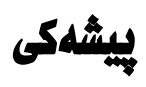

مروق هـه لهسهرهتاى دروست بوونيهوه هـاستى بهريرسياريتى تيادا بووه, ئهو بهريرسياريتيهى لهئهستوى بووه

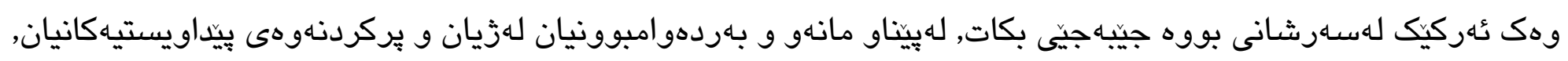

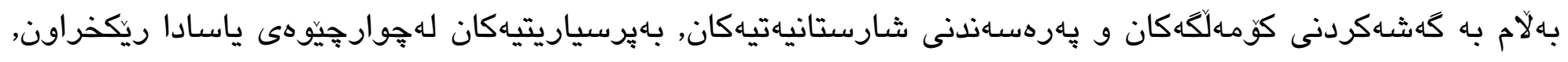

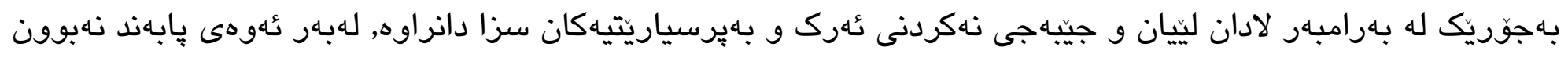

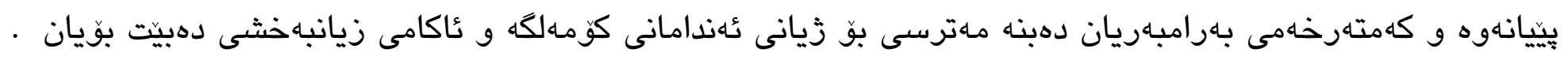

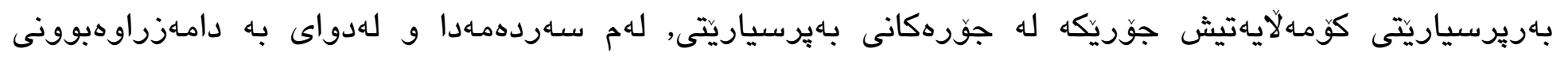

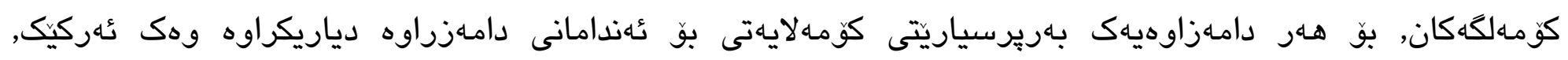

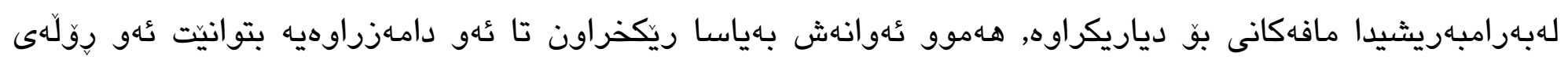

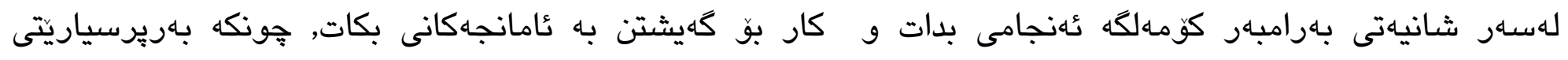

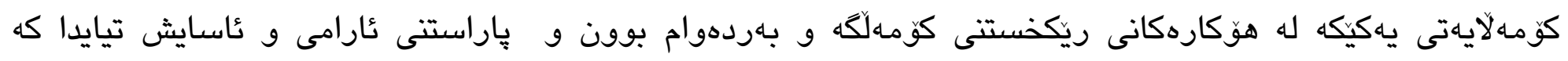

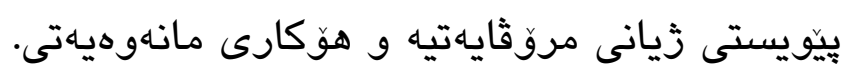




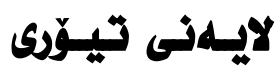

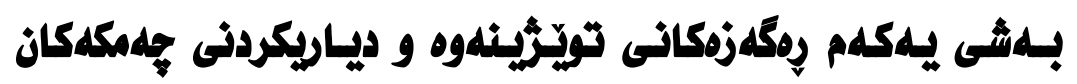

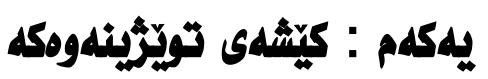

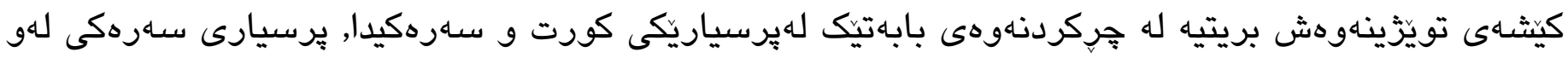

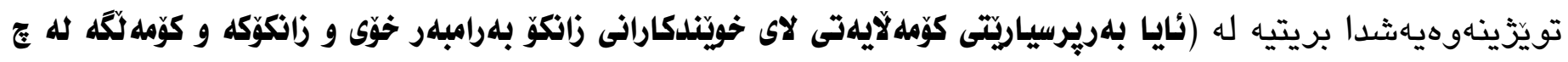

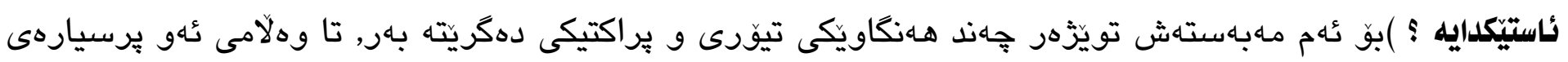
دهست بكهويّت .

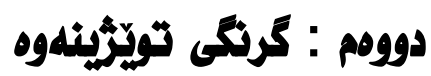

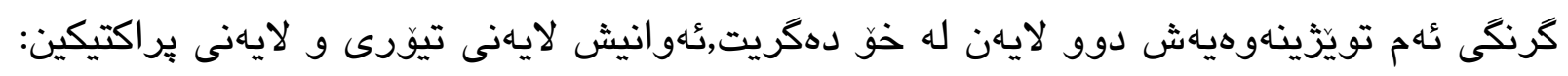

لايلهذى تيوّرى :

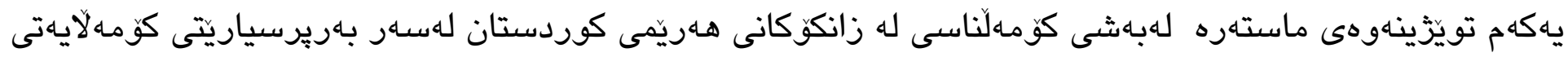

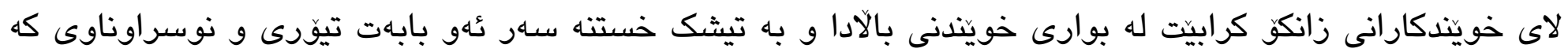

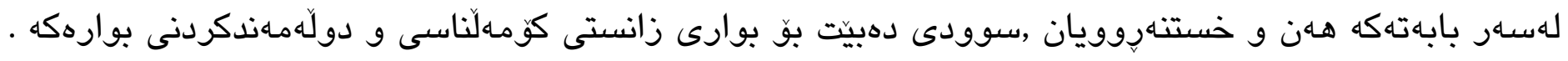

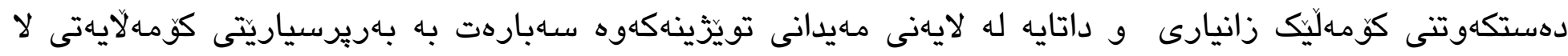

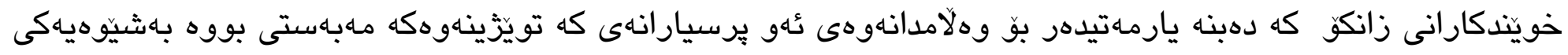

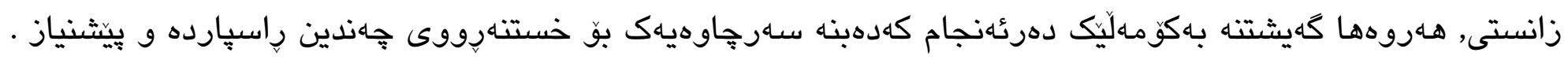

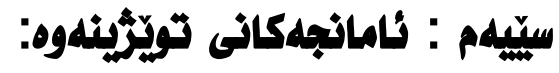

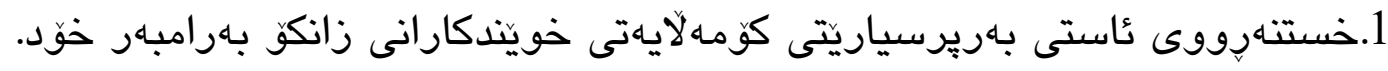

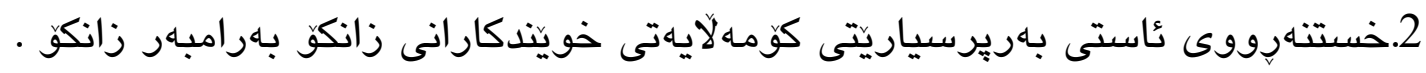

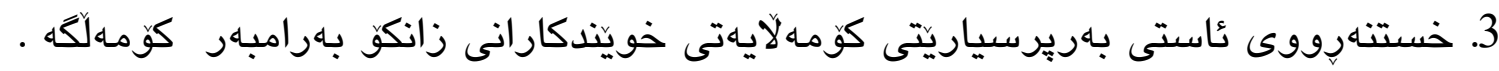

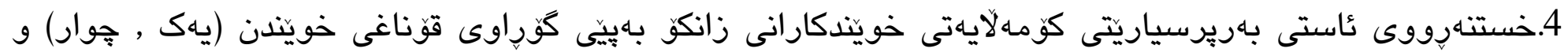
كُوراوى كوَليزى (زانستى , مروّيى) · 


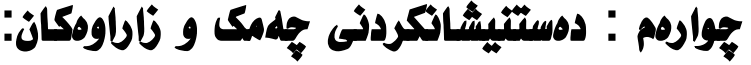

دهستنيشانكردنى جهمكهكان و يِيناسهكردنيان هاوكار دهبيت بو زياتر روونبونهوهى عامانجى تويّزينهوهكه و مانا و

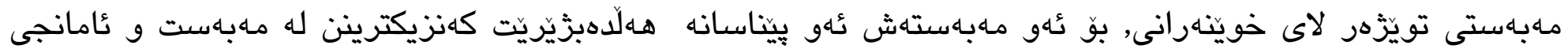

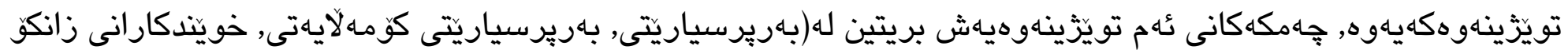

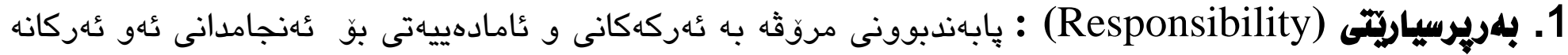

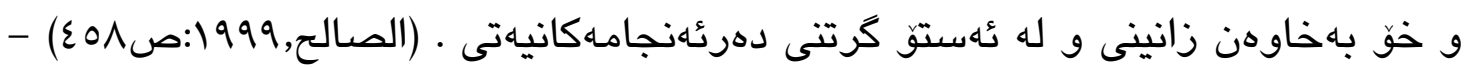

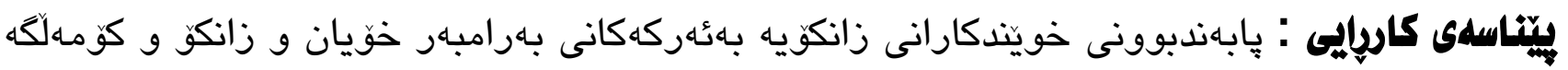

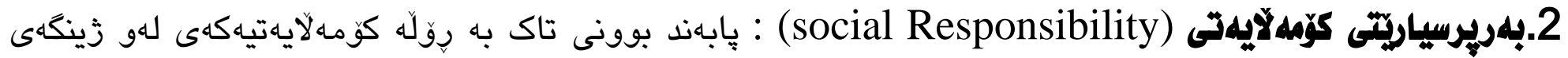

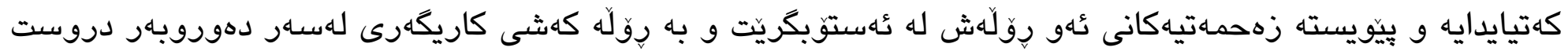

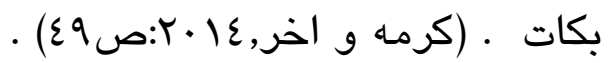

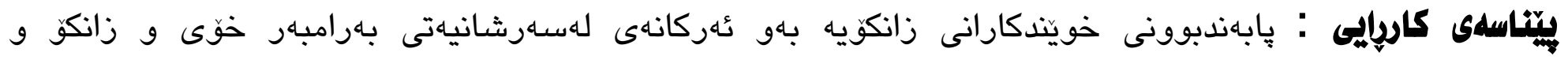

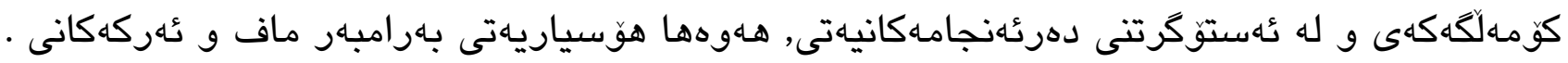

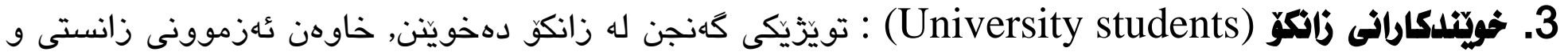

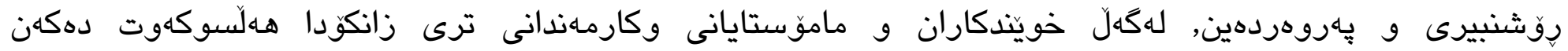

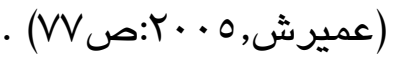

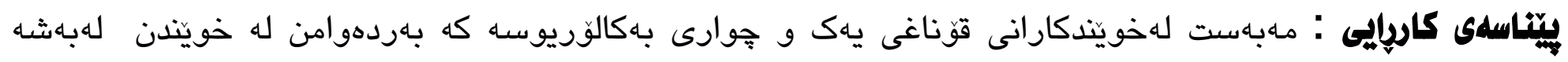
زانستى و مروّييكانى زانكوَى سليمانى . 


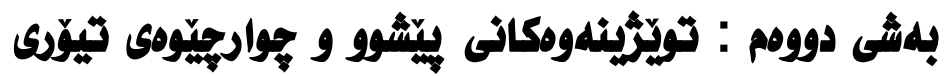

\section{يلمكلم: تويَّينهومكانى بيّشوو (The Previous Studies)}

\section{تقويْرَّينهوه كورديلهكان:}

\section{1- تويَّينهلومى عر ( 2007 )}

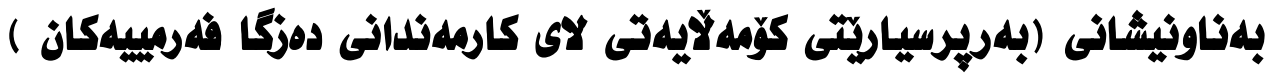

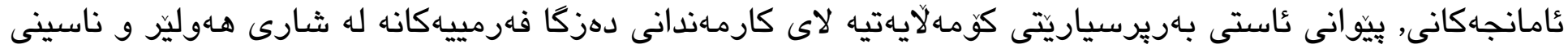

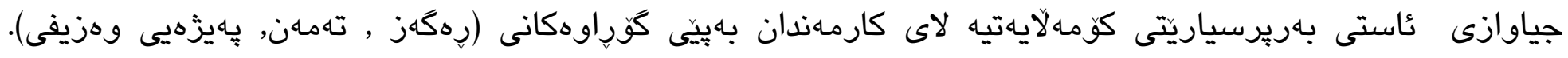

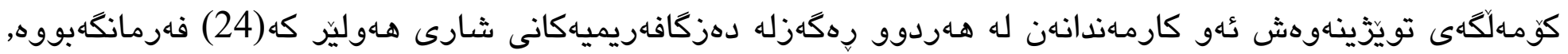

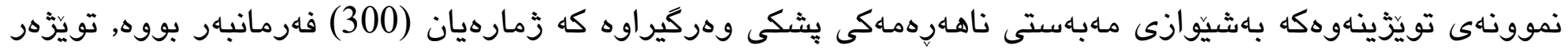

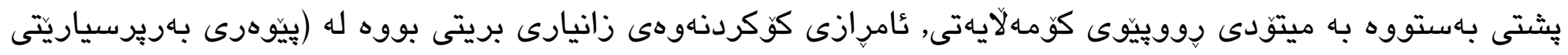

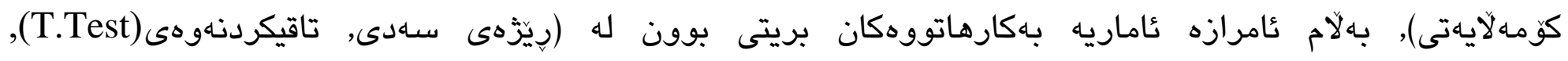

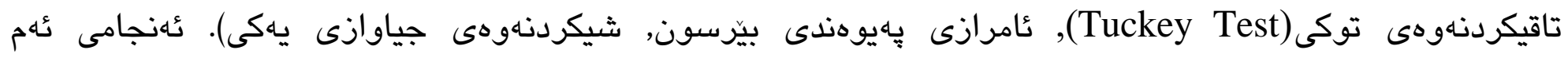

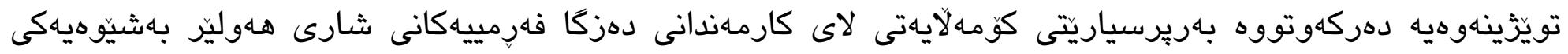
كشتى له ئاستيكى بهرزدايه. (عمر:2007)

\section{تويَّرئنهوه عهروبيهكان}

1. 1 البلوى, (2002)

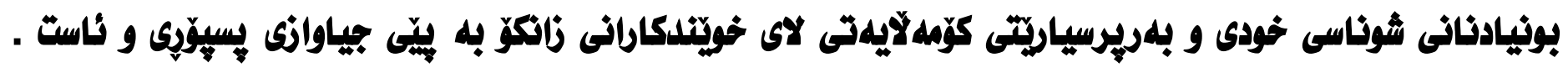

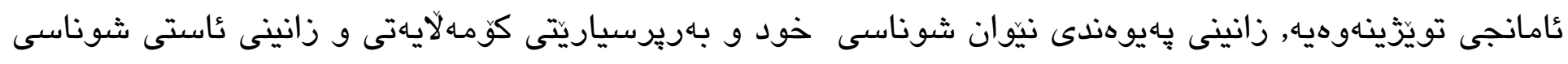

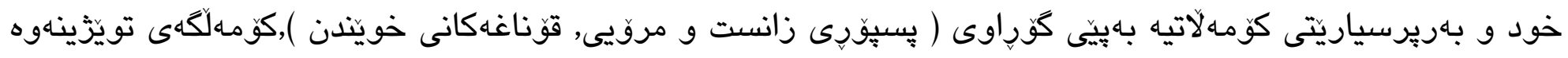

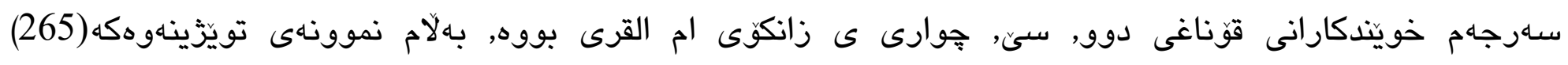

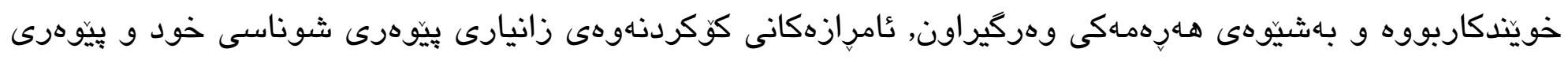

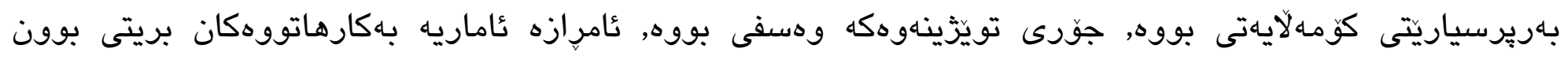




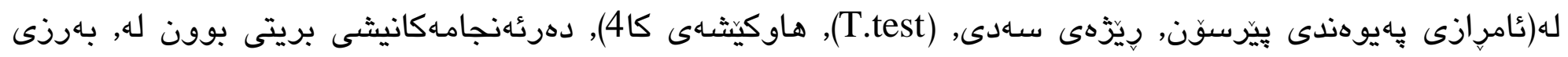

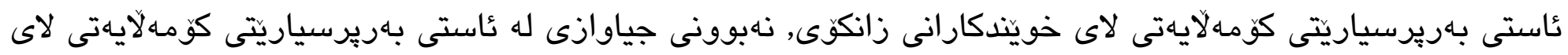

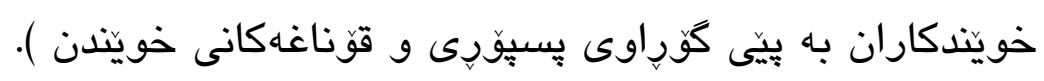

2009) مشرف (2009)

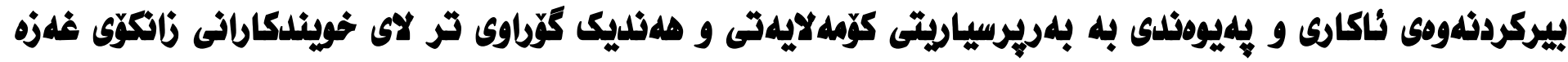

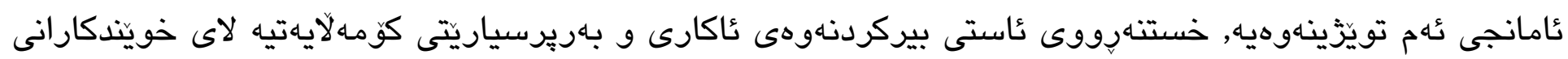

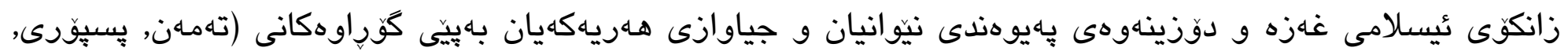

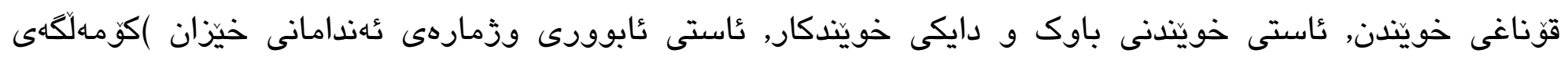

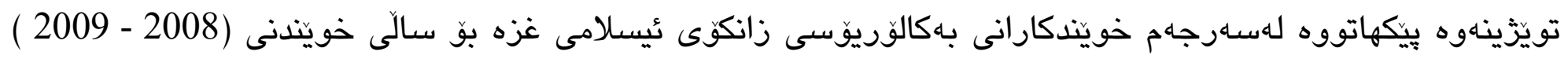

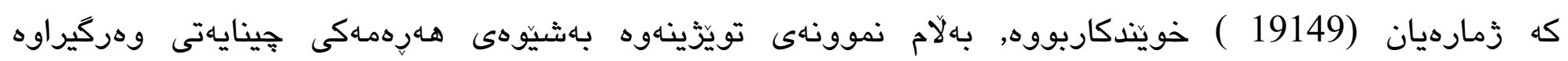

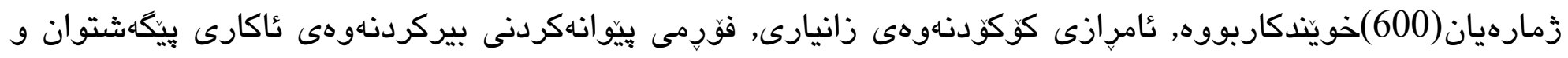

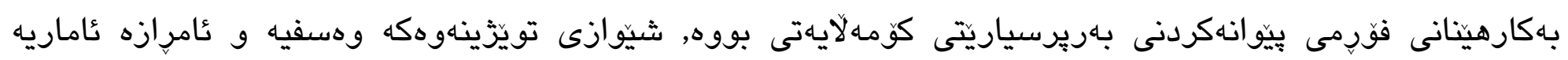

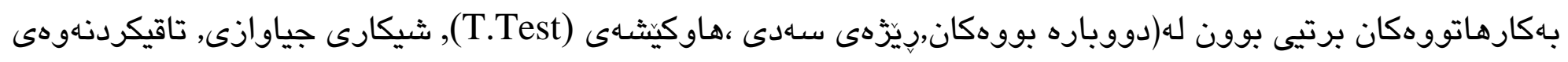

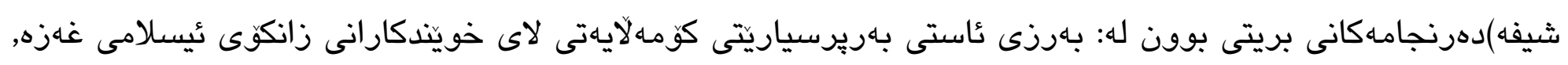

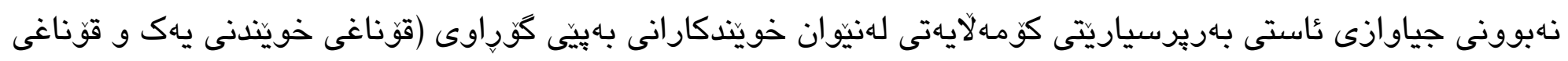

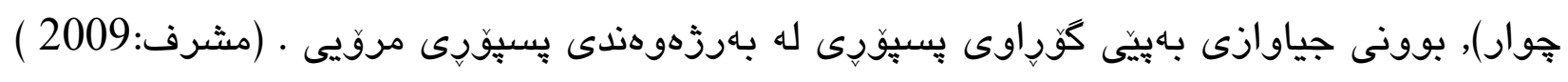

3.

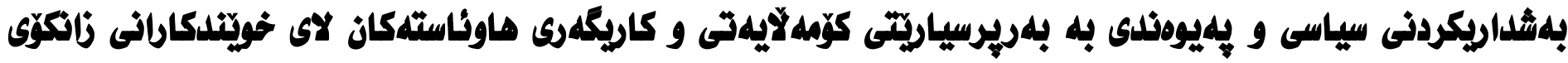

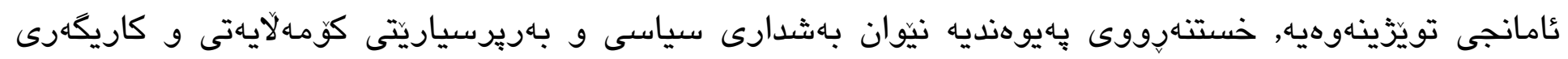
هاوئاستهكانه له نيّوان خويندكارانى زانكوى قدس و خستهرووى جياوازى ئاستى بهشدارى سياسى و بهريرسياريتى

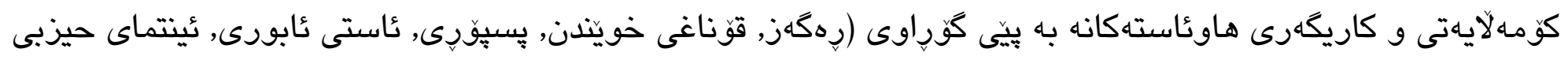
), كومهلكَهى تويّزينهوه, سـهرجهم خويّندكارانى زانكَّى قدس بوّ سالَى خويّندنى (2013 - 2014) كه زمارهيان (3638)

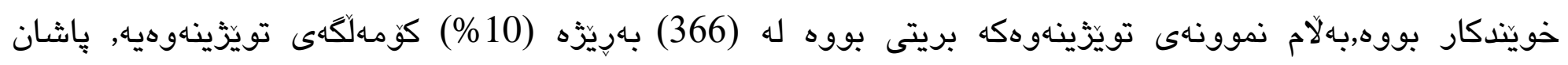

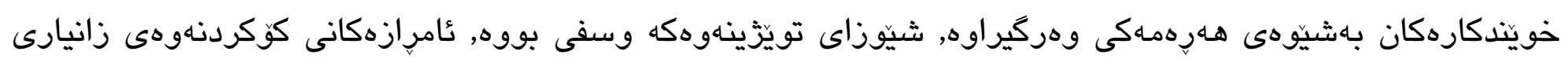

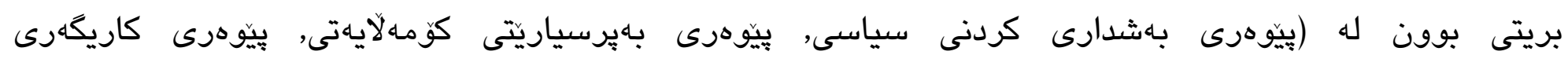


هاوئاستهكان),هـهورهها ئامرازه ئاماريه بهكارهاتووهكان بريتى بوون له (بهرنامهى (S.P.S.S.) و ناوهنده زميرهيى,

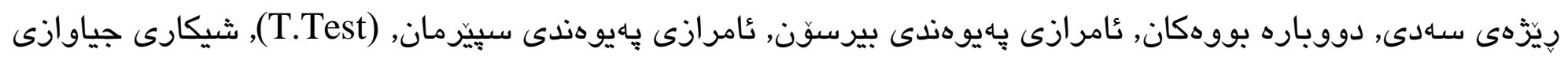

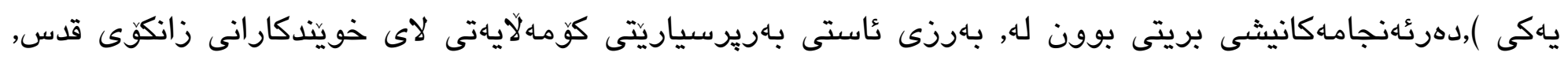

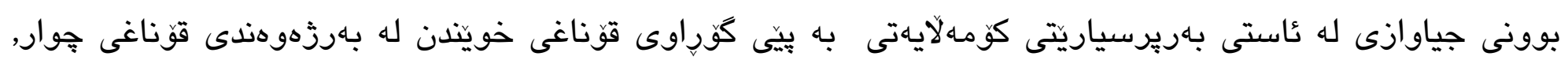

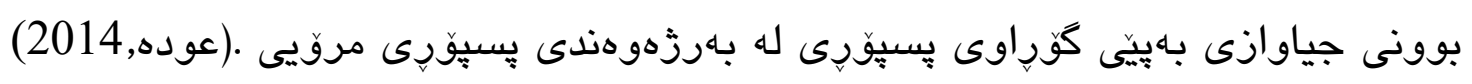

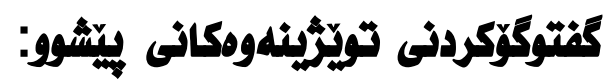

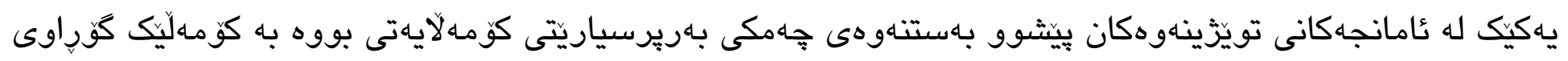

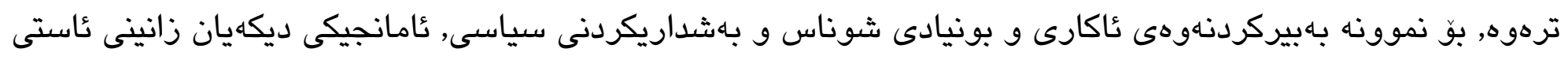

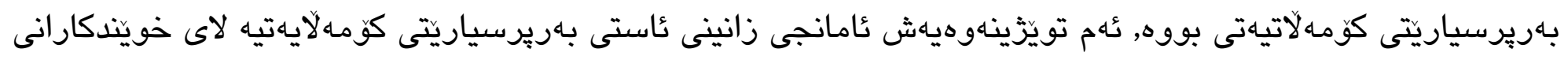

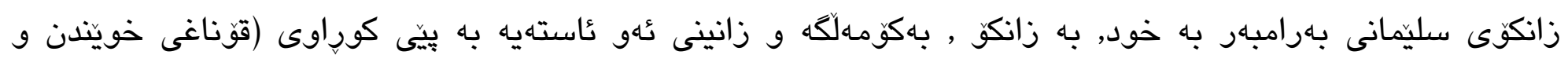

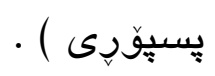

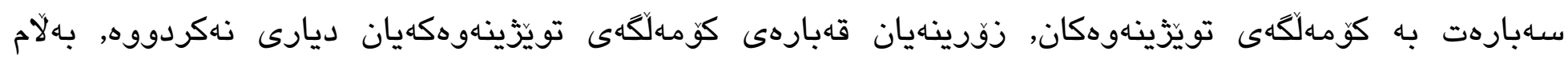

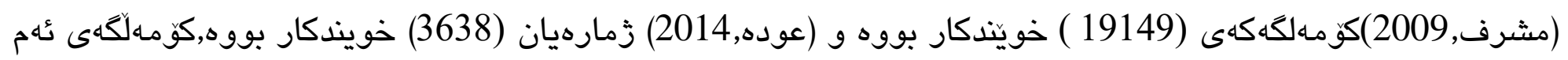

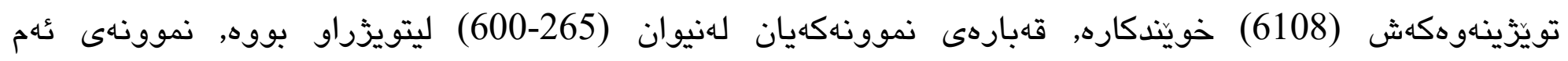

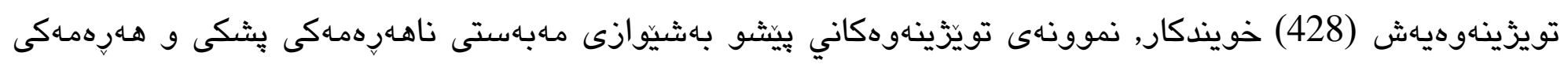

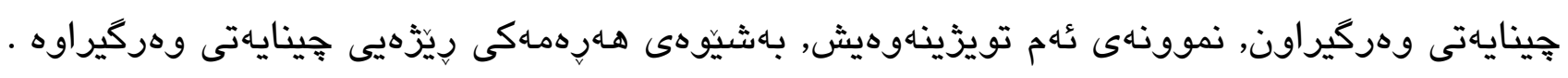

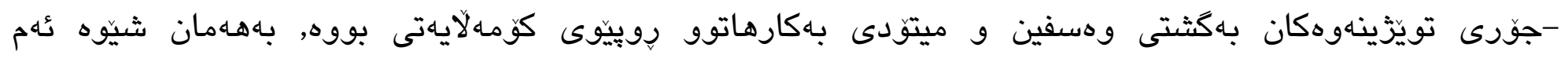

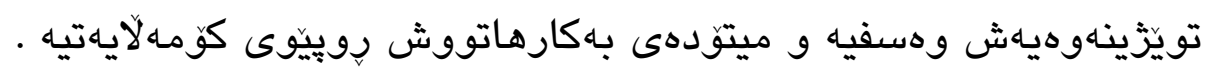

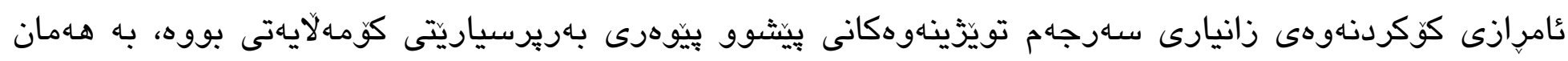

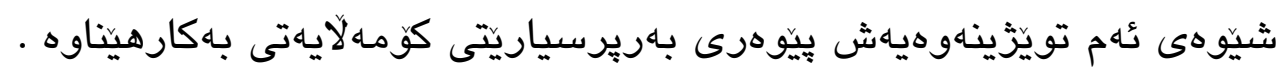

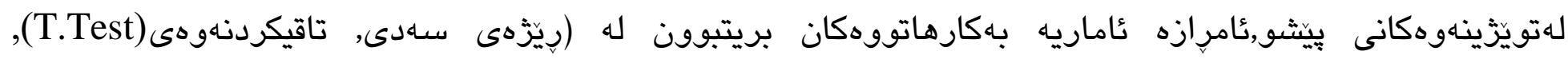

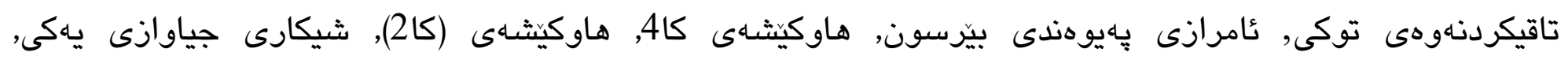

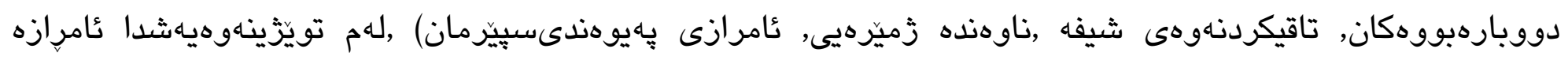

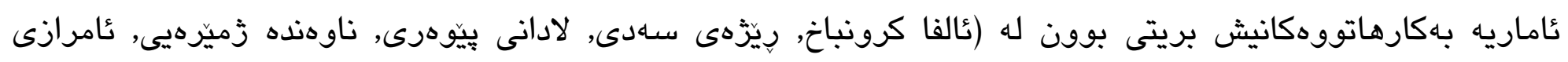

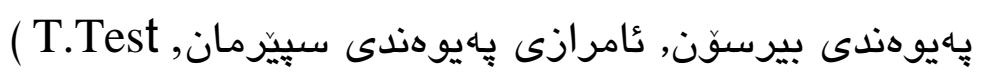




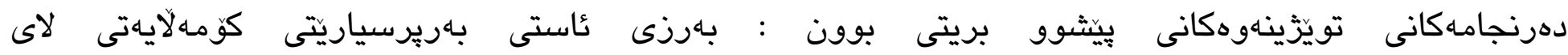

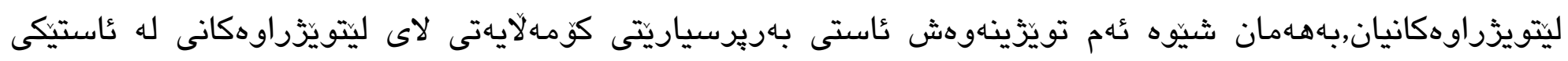

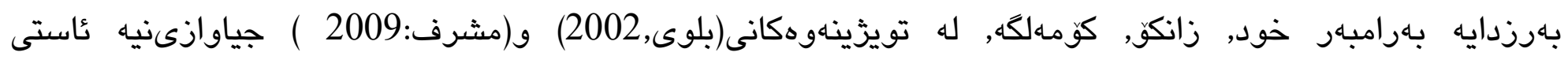

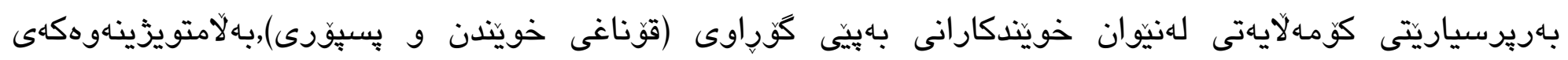

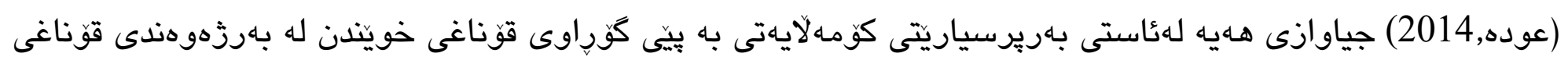

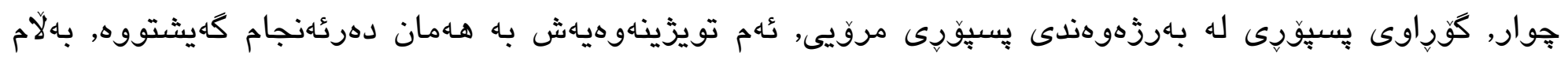

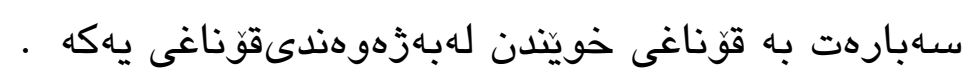

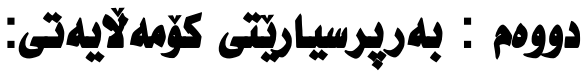

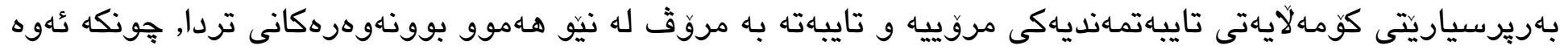

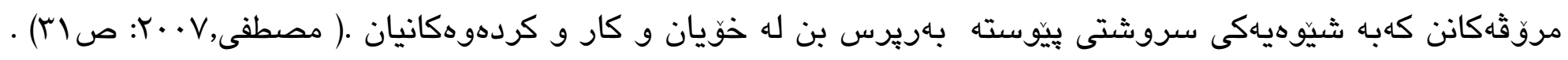

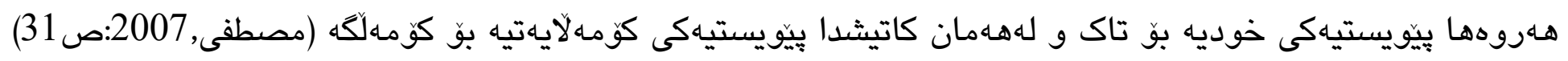

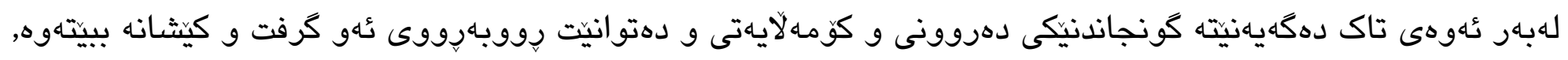

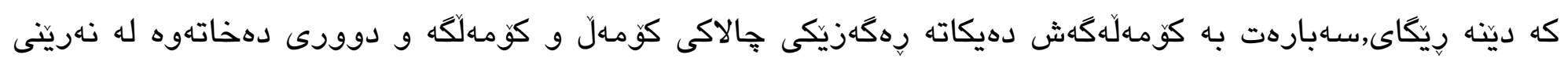

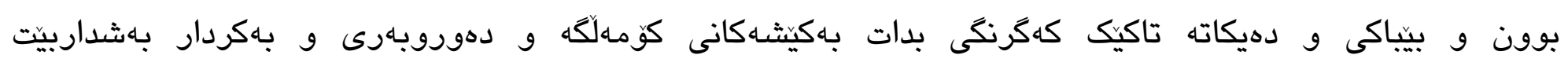

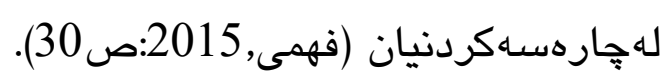

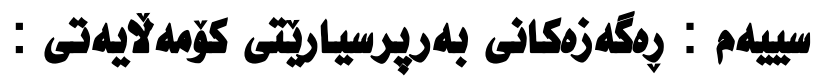

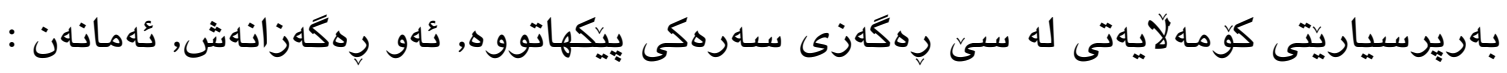

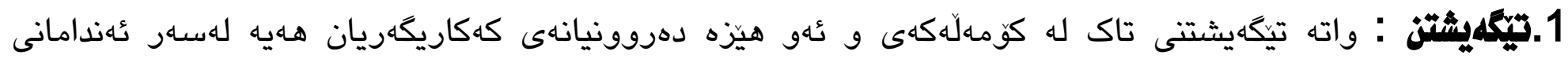

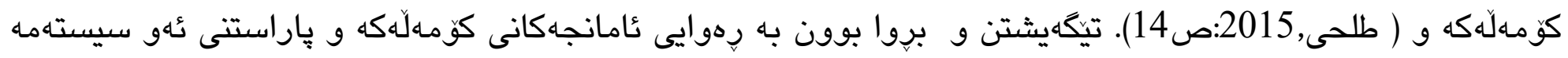

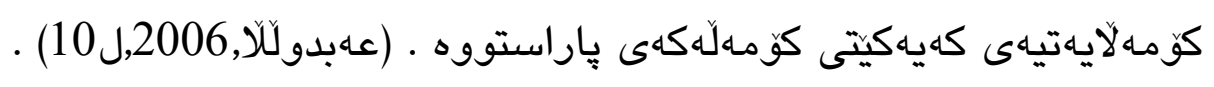

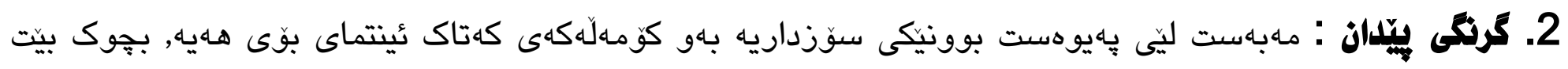

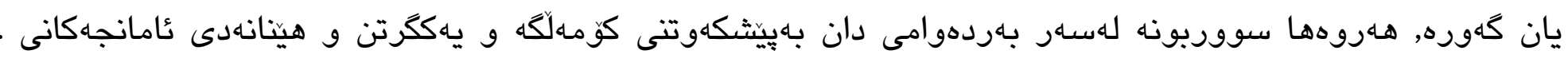

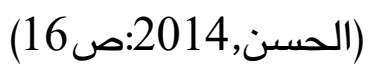




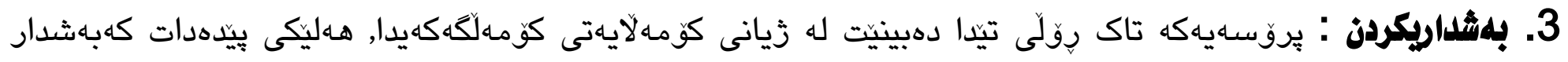

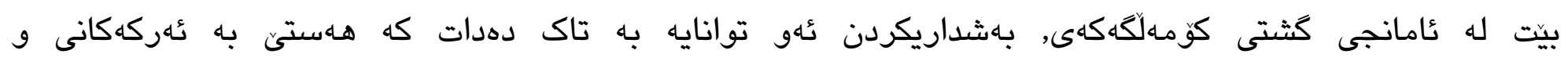

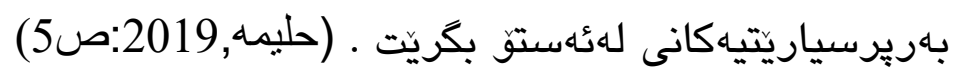

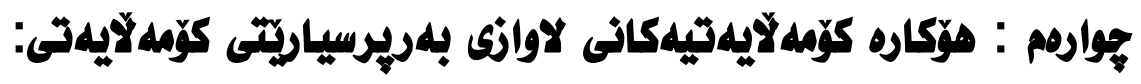

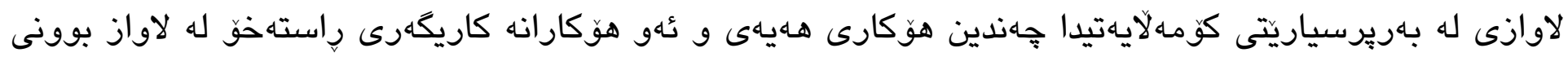

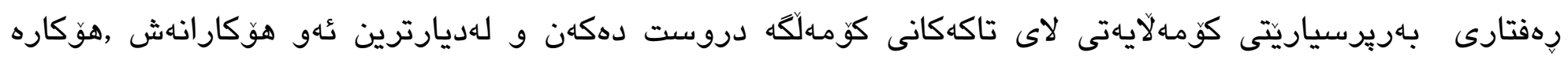

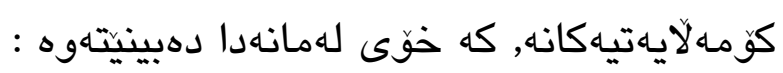

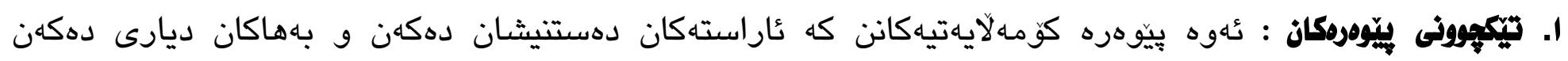

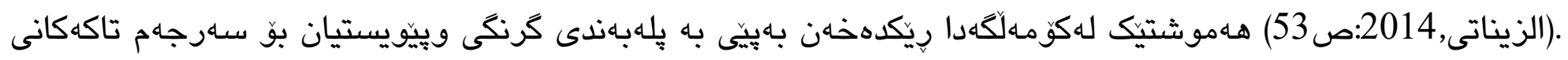

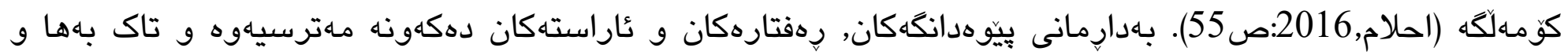

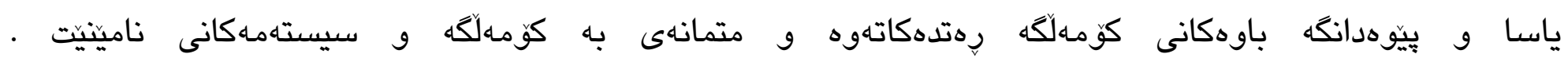

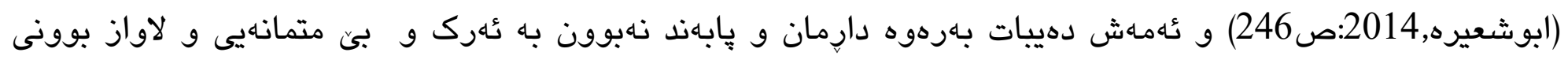

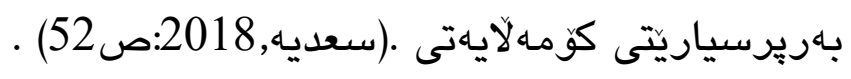

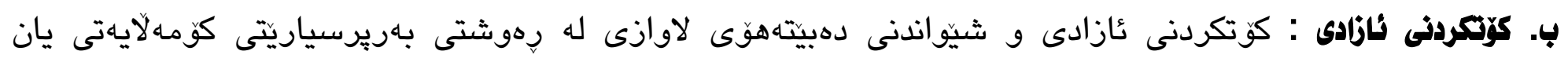

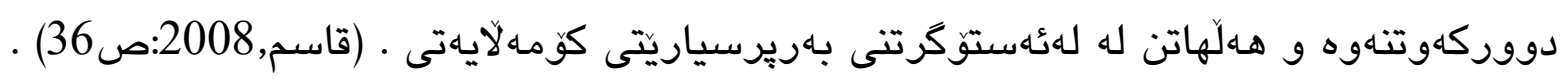

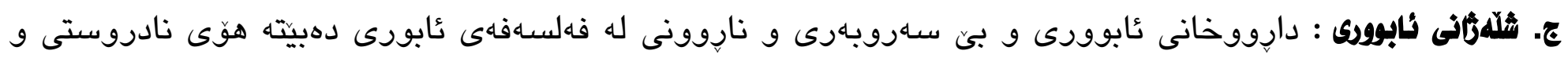

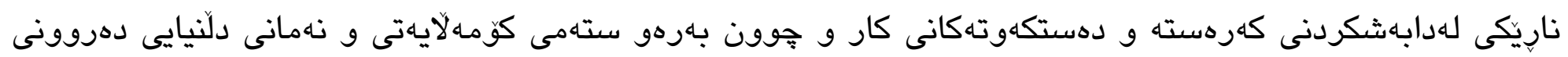

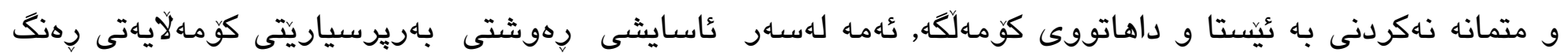

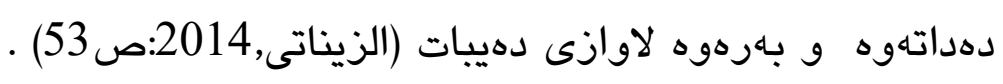




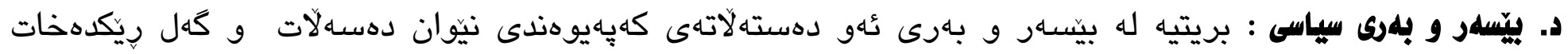

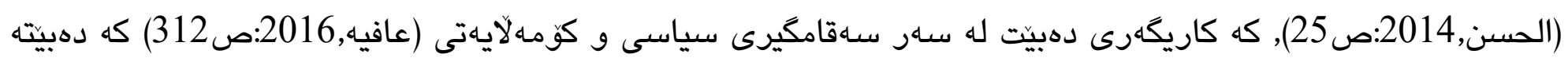

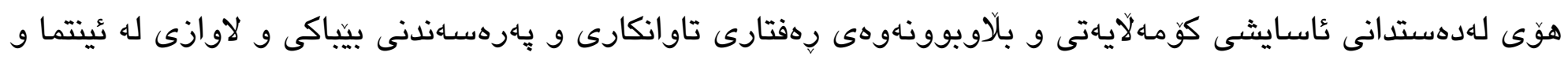

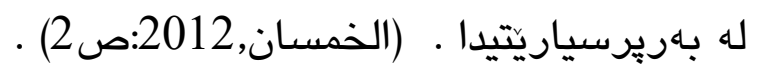

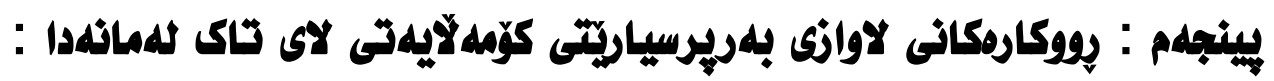

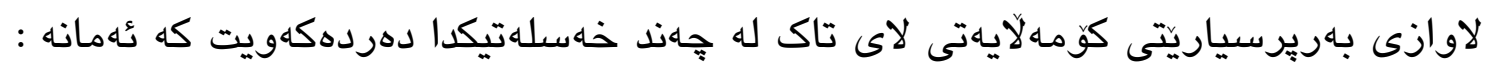

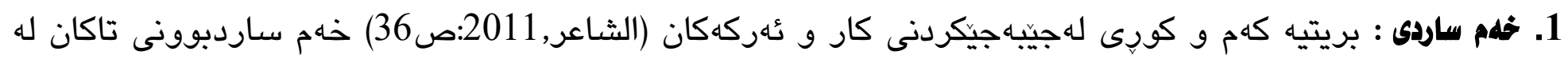

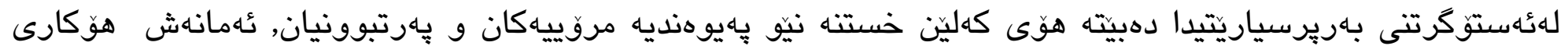

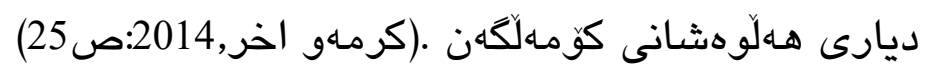

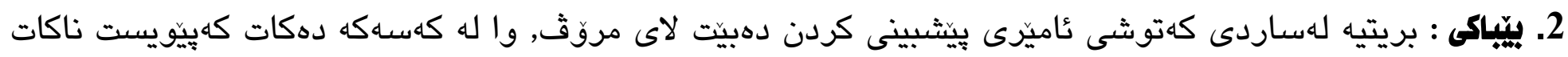

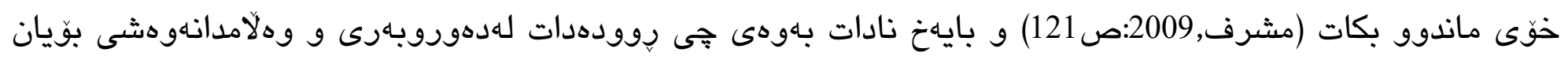
نابيت (بدوى, 1982:صوك ماندو بكات (23)

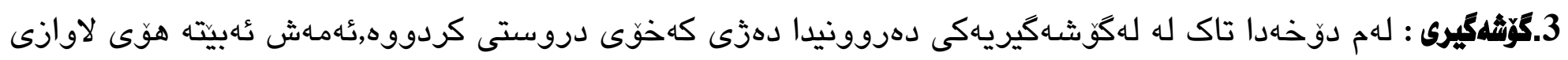

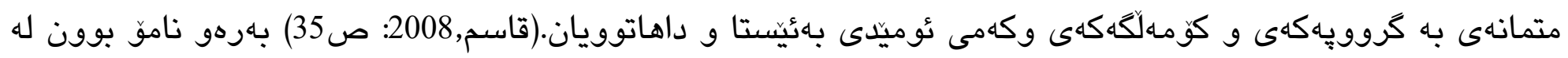

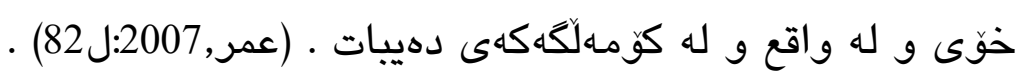




\section{شاشهله : خمويتلدكارانى زانكو:}

خويندكارى زانكو تويَزيكى كَهن و هيشتا لهدهرهوهى بازنهى كاردان, لهدوخى يِيكّهاندنى كولتورى زانكويدان و

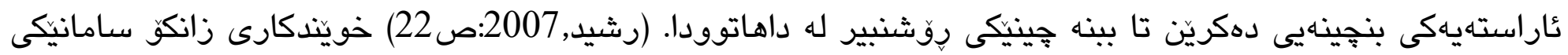

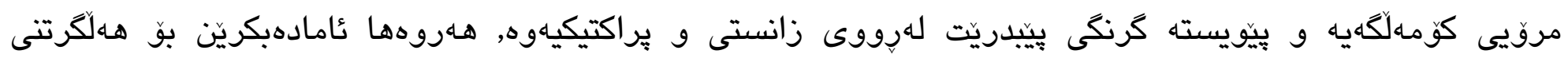

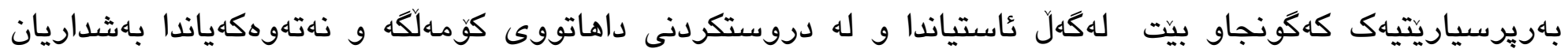

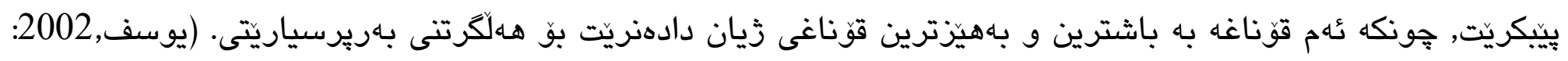

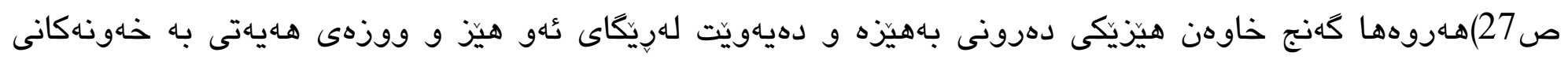

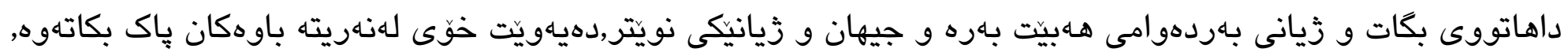

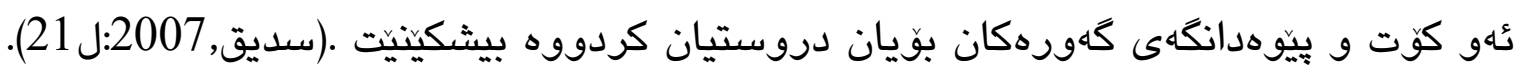

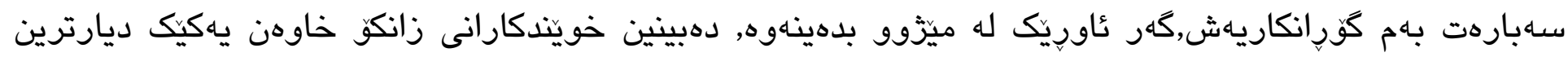

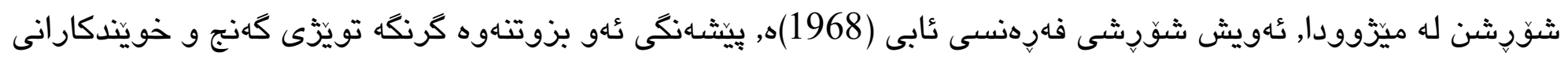

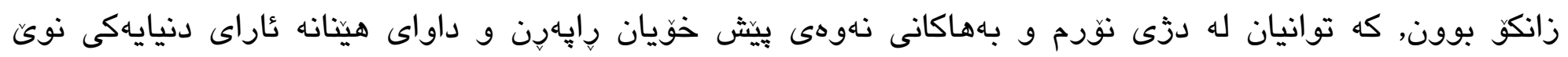

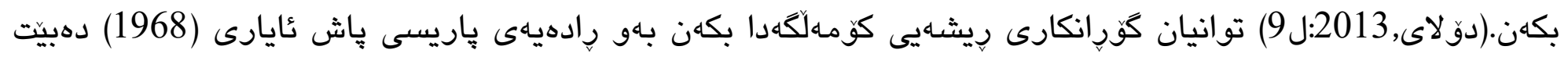

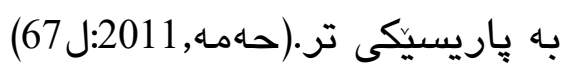

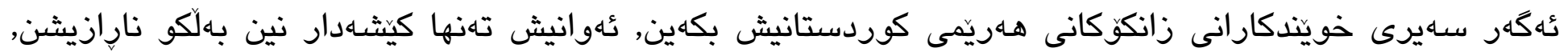

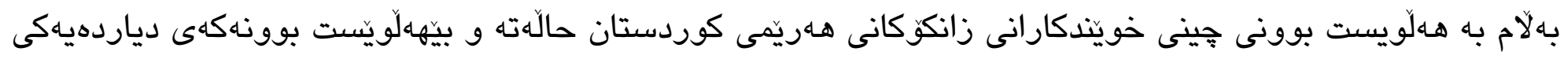

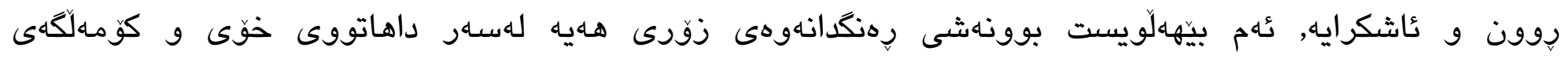

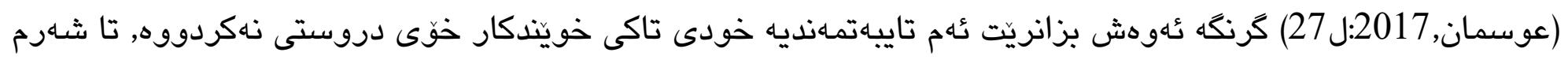

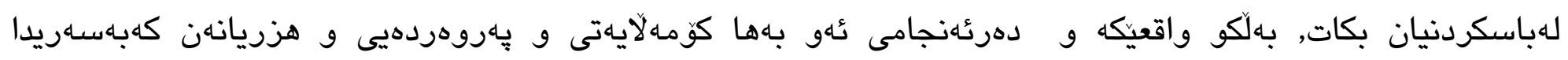

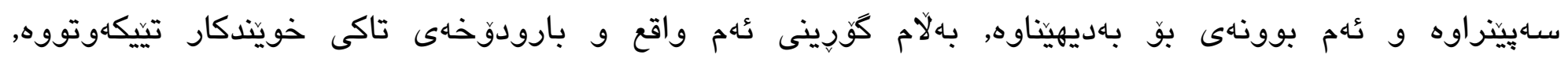

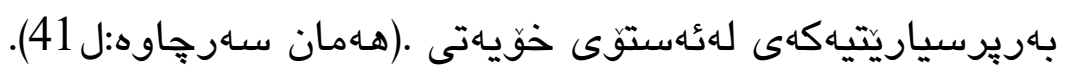

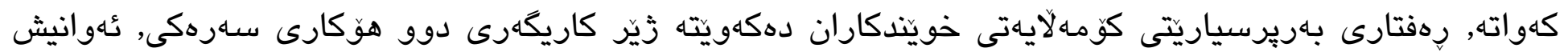

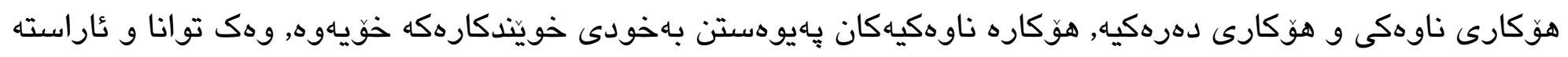

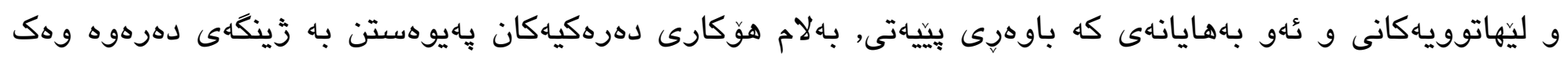

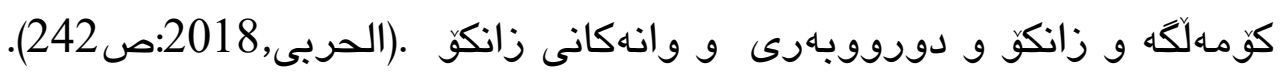




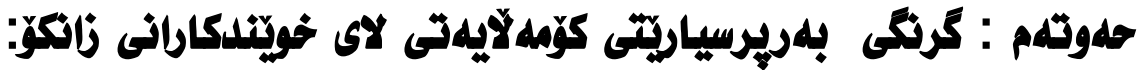

بهارزى هاهتى بهريرسياريتى كومهلايهتى كاريكارى دهبيت له شيّوازى هـلّ و كهوت و جوّنيهتى بيركردنهوهى

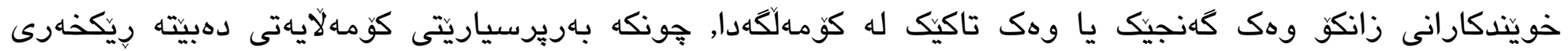

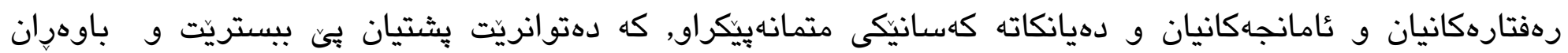

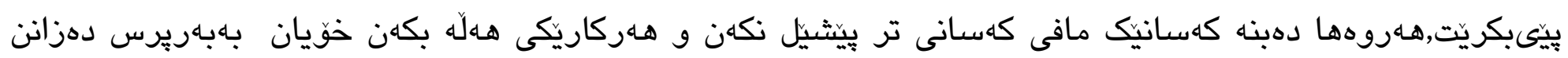

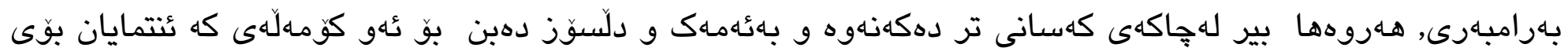

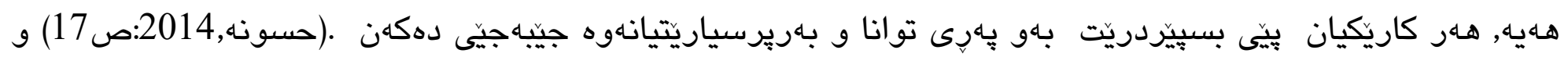

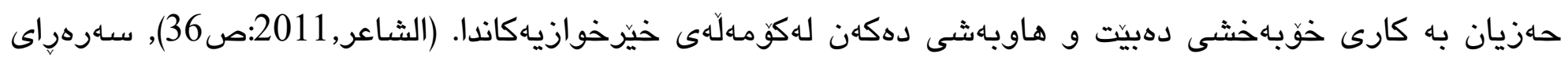
عُهوانهش هـست به بههاى كات دهكهن و كرنكيهكهى دهزانن و كاته بهتالّكانيان بهكاردهينين بو سوودى خوّيان و

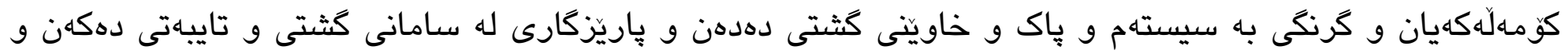

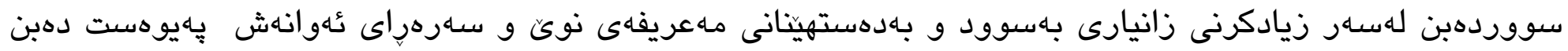

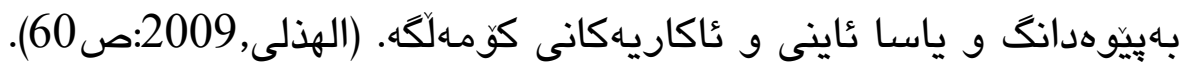

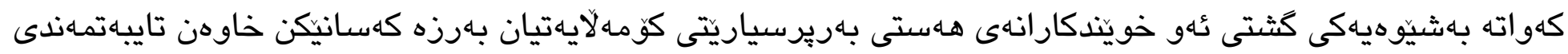

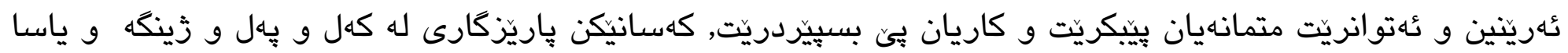

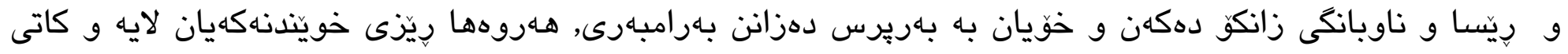

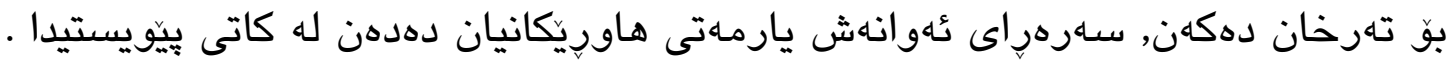

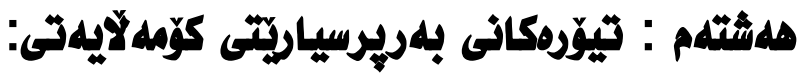

\section{1}

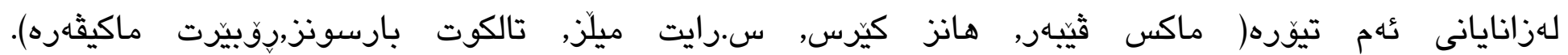

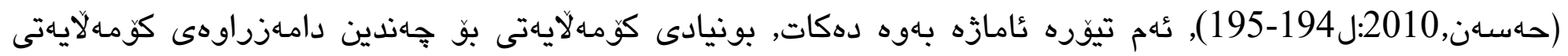

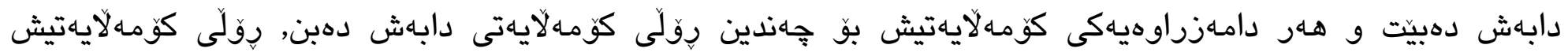

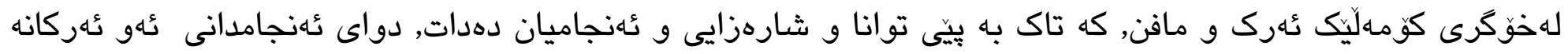

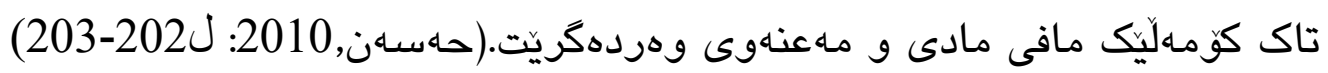

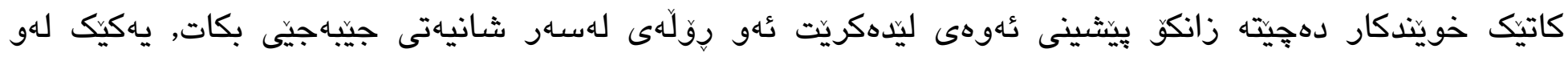

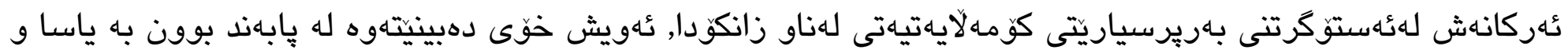




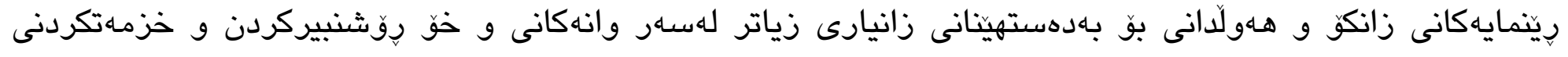

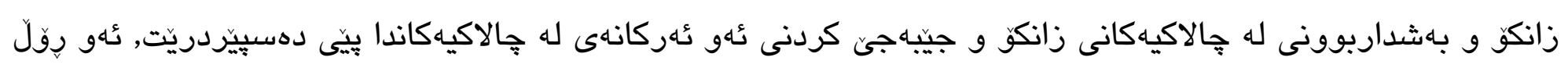

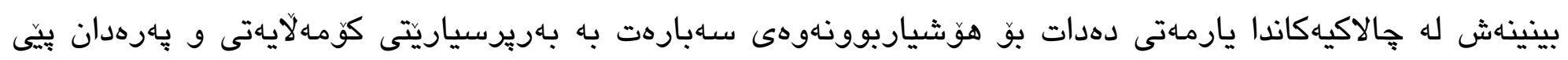

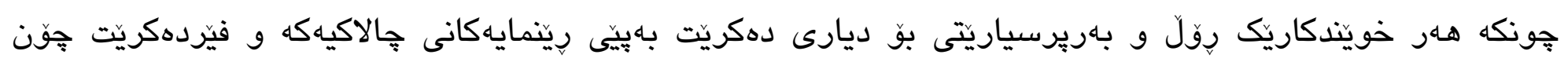

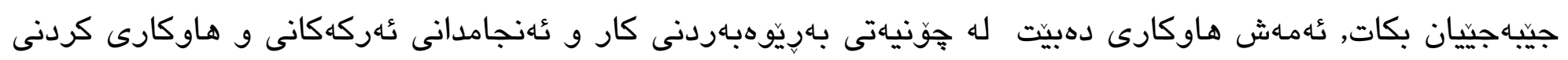

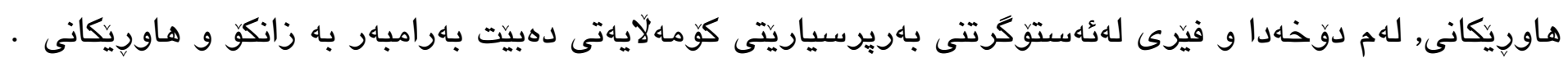

\section{2. تيوّرى بِيّلاوديستيهكان:}

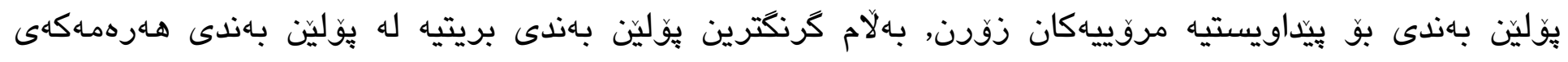

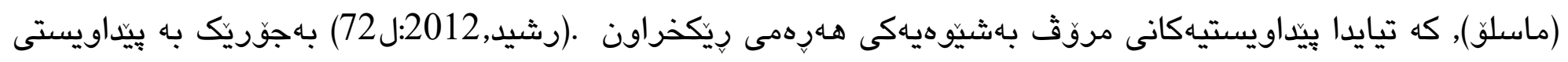

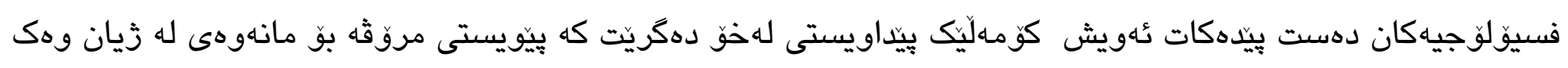

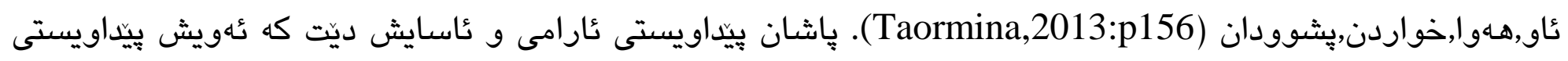

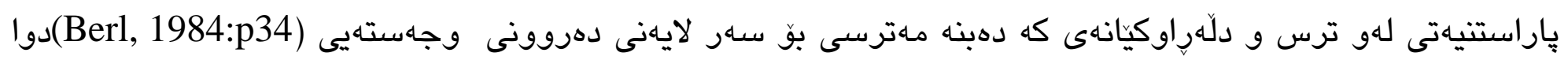

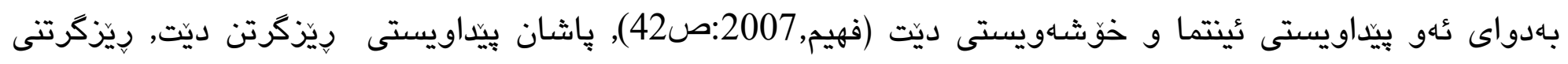

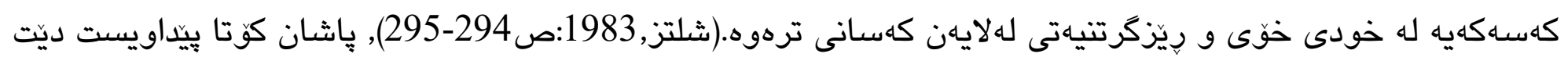

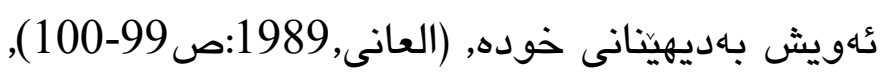

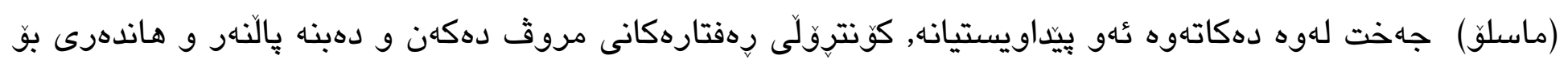

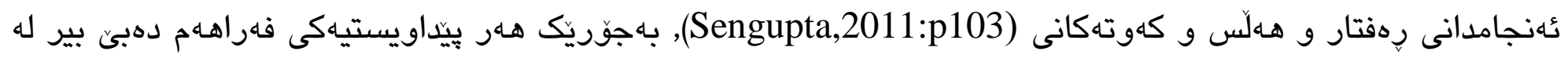
يِيداويستى دواى ئهوه دهكاتهوه .

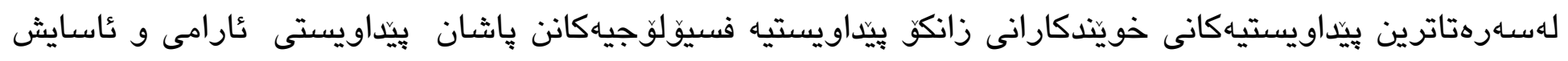

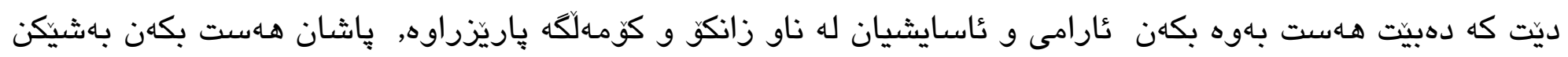

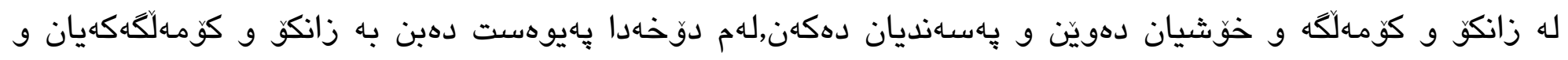

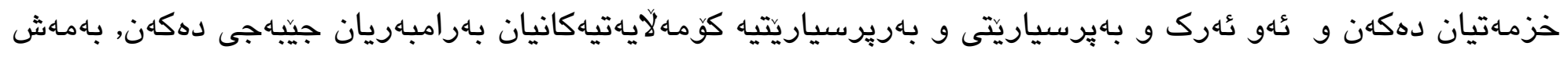

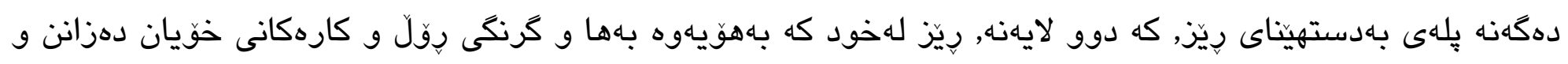

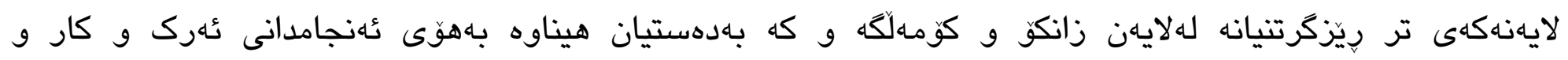

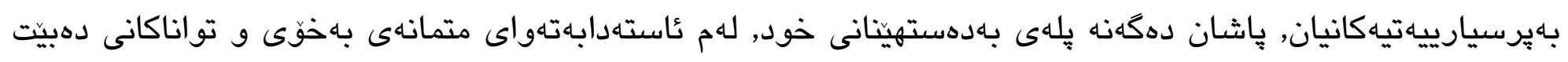


و دهزانيت ئهوهى دهيهويت دهتوانيت بيكات , هـهر بوّيه بهريرسياريتيه كومهلآيهتيهكانيان لهبهرزترين يلهدا له ئهستو

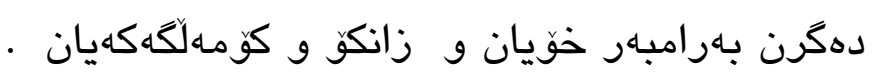

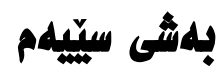

\section{ريّكاره مهيلاتيهكانى تمويّزينهوه}

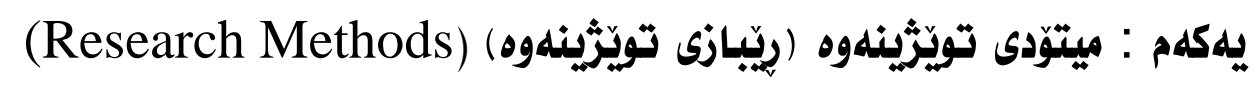

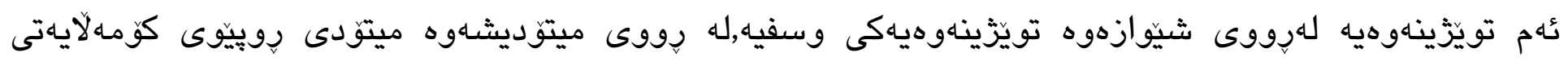
بهارهاتووه.

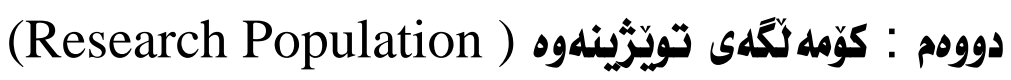

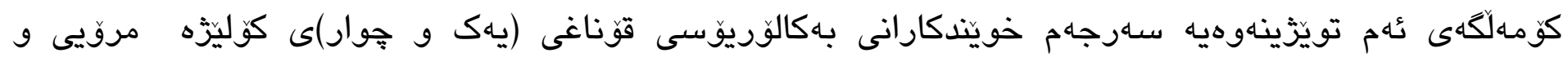

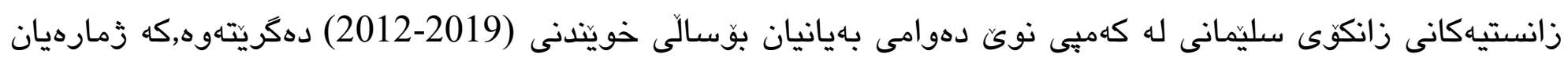
. (6108) خويندكاره

\section{(Research Sample) سيّيهم : نسووثلى تويَّرينهوه}

نموونهى تويزّينهوهى بهشيّوهى هـرهمهكى ريّزّهيى جينايهتى(عينة العشوائية التناسبية الطبقية) وهركيراوه به وييّى

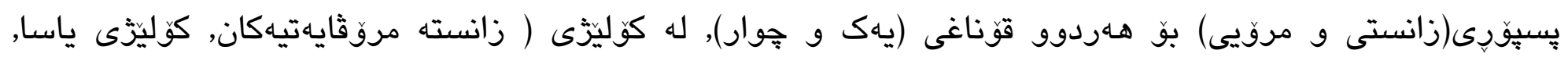

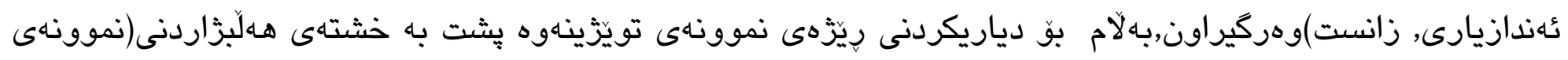

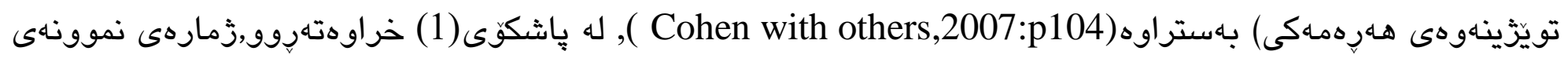

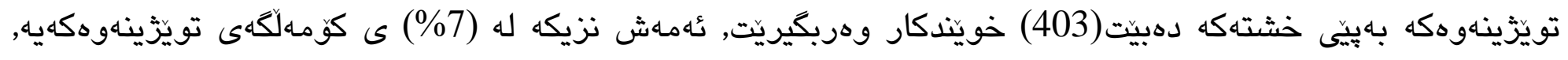

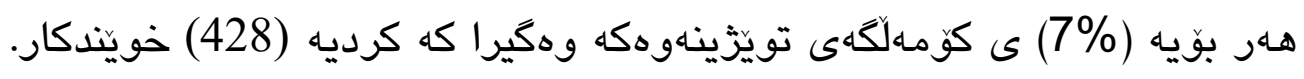

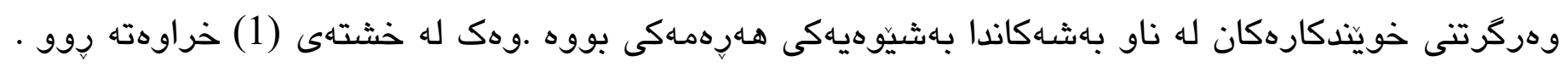


خشتهى(1) نموونهى تويّزينهوه به بيّى بهش

\begin{tabular}{|c|c|c|c|c|c|c|c|}
\hline \multirow{2}{*}{ كثنى } & \multirow[t]{2}{*}{ كو } & \multicolumn{4}{|c|}{ قوّناغ } & \multirow[t]{2}{*}{ بهاش } & \multirow[t]{2}{*}{ كوليَّز } \\
\hline & & رِيَّه & جوار & ريّزَه & يهك & & \\
\hline \multirow{8}{*}{317} & 33 & $\% 4.90$ & 21 & $\% 2.80$ & 12 & ميَّزوو & \multirow{7}{*}{ مروّثايهتيهكان زانسته } \\
\hline & 33 & \%4.43 & 19 & \%3.27 & 14 & شوينَهوار & \\
\hline & 45 & \%6.54 & 28 & \%3.97 & 17 & كار & \\
\hline & 46 & \%6.30 & 27 & \%4.43 & 19 & كوّمهلناسى & \\
\hline & 37 & \%5.84 & 25 & $\% 2.80$ & 12 & جوكرافيا & \\
\hline & 30 & \%2.80 & 12 & \%4.20 & 18 & راكهياندن & \\
\hline & 17 & & - & \%3.97 & 17 & فهلسهافه & \\
\hline & 76 & \%9.11 & 39 & $\% 8.64$ & 37 & ياسا & ياسا \\
\hline \multirow{8}{*}{111} & 18 & $\% 2.33$ & 10 & $\% 1.86$ & 8 & سـارجهاوهكانى & \multirow[t]{4}{*}{ ئهندازيارى } \\
\hline & 10 & \%1.40 & 6 & $\% 0.93$ & 4 & شارستانى & \\
\hline & 12 & \%1.63 & 7 & \%1.16 & 5 & تهلارسازى & \\
\hline & 15 & \%1.86 & 8 & \%1.63 & 7 & كارهبا & \\
\hline & 15 & $\% 2.10$ & 9 & $\% 1.40$ & 6 & كيميا & \multirow[t]{4}{*}{ زانست } \\
\hline & 15 & \%1.86 & 7 & \%1.86 & 8 & كومبيوتهر & \\
\hline & 14 & \%1.16 & 5 & \%2.10 & 9 & جيولوَجى & \\
\hline & 12 & \%1.16 & 5 & \%1.63 & 7 & بايولوَجى & \\
\hline \multirow[b]{2}{*}{428} & \multirow[b]{2}{*}{428} & \%53.43 & \multirow[b]{2}{*}{228} & \%46.65 & \multirow[b]{2}{*}{200} & \multirow{2}{*}{\multicolumn{2}{|c|}{ كوى كشتى }} \\
\hline & & 100 & & 100 & & & \\
\hline
\end{tabular}

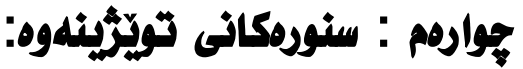

1. سنورى جوكرافق: زانكوى سليمانى,كهمبى نويّى زانكق, دهوامى بهيانيان بوّ سالّى خويندنى (2019 - 2020)

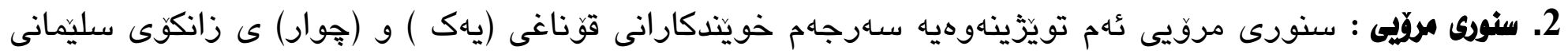

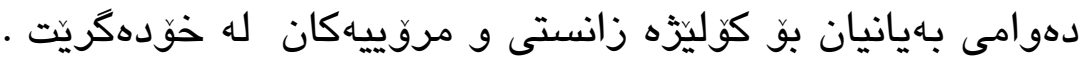


3. سنورى كاتى : مهابهت له سنورى كاتى ئهو ماوه زهمهنيهيه كه بِيّويست بووه بو نُهنجامدانى كاره مهيدانهيهكانى

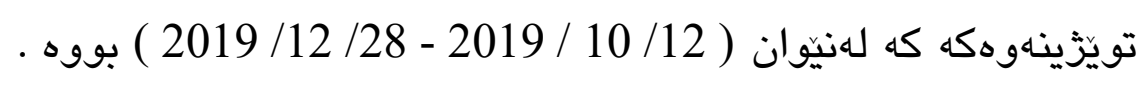

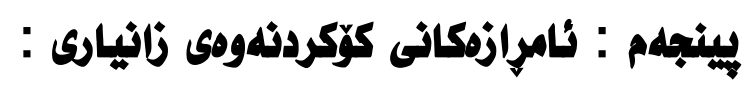

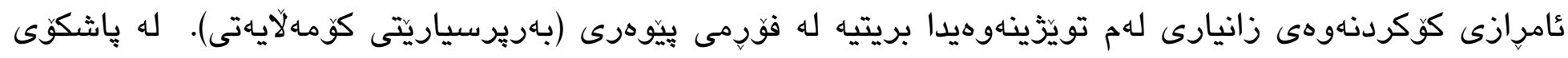

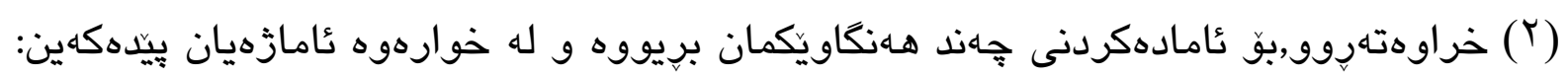

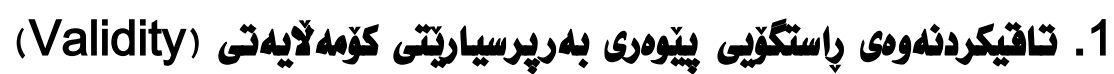

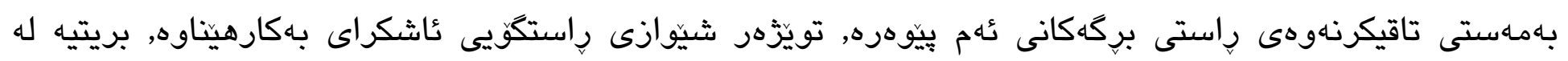

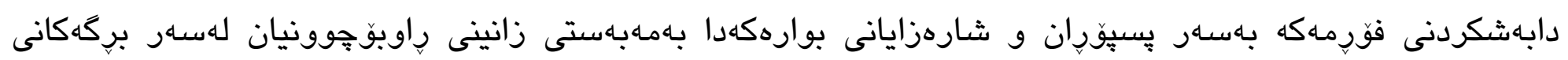

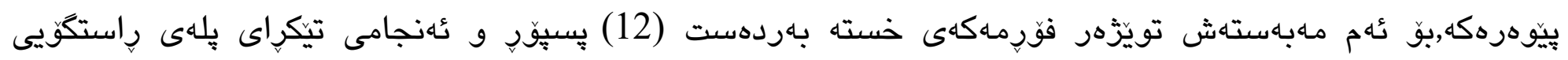

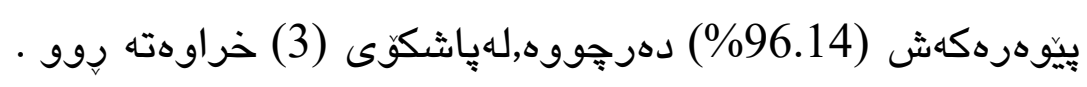

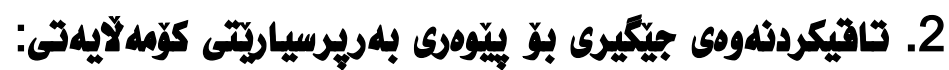

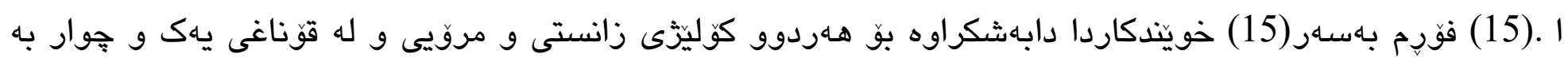

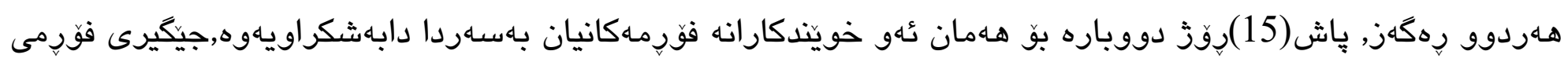

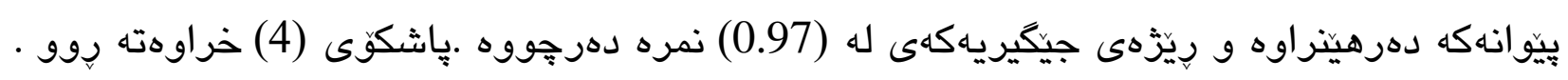

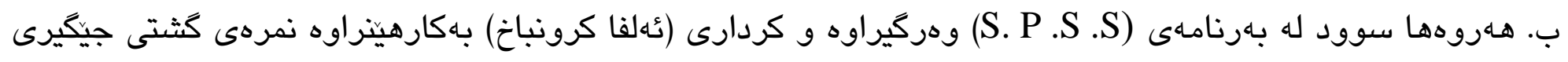

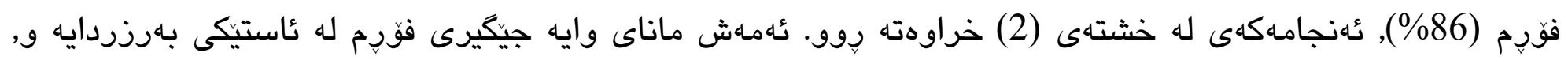
كونجاوه بو جيّبه جينكردن . 


\section{خشتهى(2)}

\section{جيكيرى فوّرمى بيّوانهكه دهخاته روو}

\begin{tabular}{|c|c|c|}
\hline ز زمارهى برِكه & ئنجامى ئهلفا كرونباخ & ت ت ت توهرهكان \\
\hline 16 & 0.66 & بهاريرسياريتى كومهالايهتى بهرامبهر خود \\
\hline 19 & 0.83 & بهاريرسياريتى كومهلاياهتى بهرامبهر زانكو \\
\hline 17 & 0.76 & بهريرسياريتى كومهلآياهتى بهارمبهر كومهلكَه \\
\hline 52 & 0.86 & ييّوهرى بهريرسياريتى كومالآيهتى بهكثتى \\
\hline
\end{tabular}

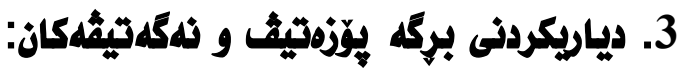

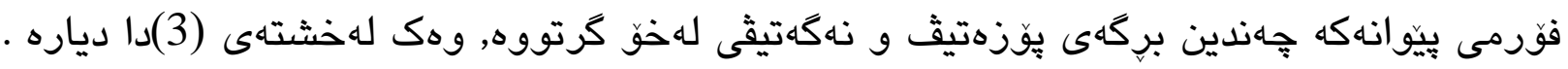

خشتهى (3)

بركه يوزذهتيف و نهكهتيفهكان

\begin{tabular}{|c|c|c|c|c|}
\hline 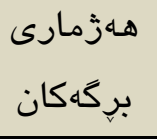 & ناهكهتيثهكان & 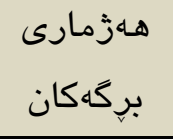 & بركها يِوزهتيڤهكان & تاهوهرهكان \\
\hline 7 بركة 7 & $\begin{array}{l}, 9,7,4,5 \\
.17,14,11\end{array}$ & 10 بركه & 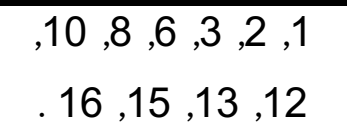 & بهريرسياريتى كومهلاياهتى بهرامبهر \\
\hline 2 & 13,9 & 18 بركه & 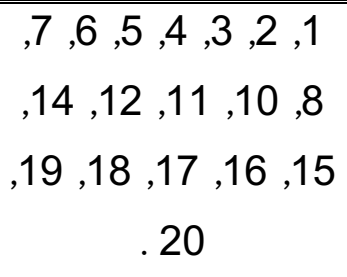 & بهابرسياريتى كومهلايهتى بهرامبهر \\
\hline 3 بركه & 9, 11, 17. & 14 بركه & 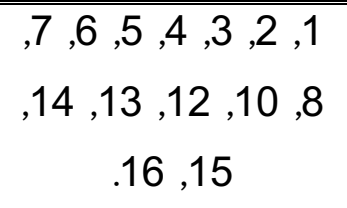 & باريرسياريتى كومهلايهاتى بهرامبهر \\
\hline
\end{tabular}




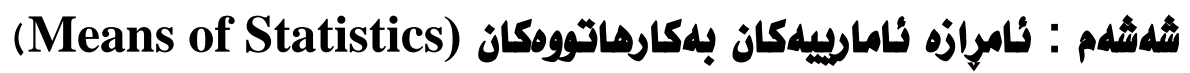

$$
\begin{aligned}
& \text { ئامرازه ئامارييهكان بهكارهاتووهكان بريتي بوون له : }
\end{aligned}
$$

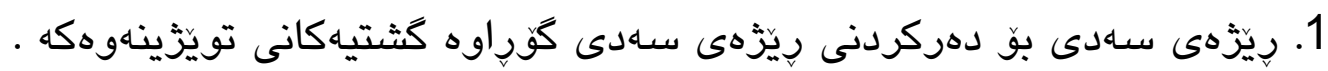

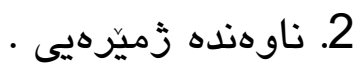

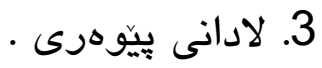

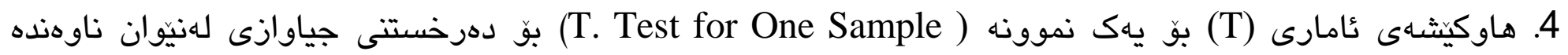

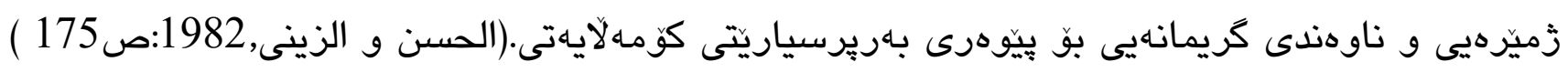

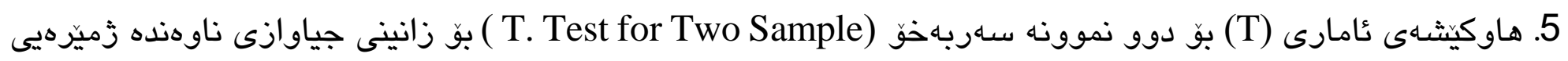

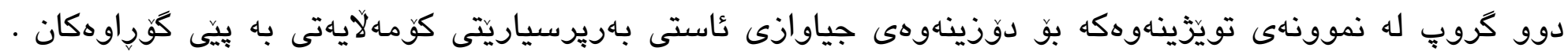
(Mindrila, 2013:p4)

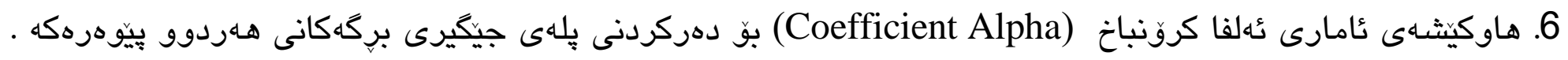
(Neuman,2014:p376)

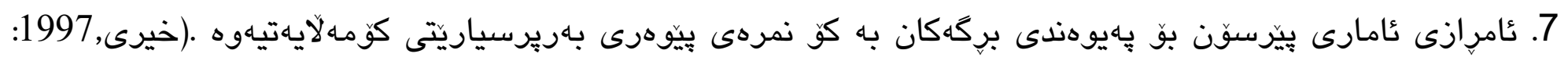

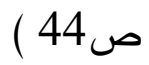

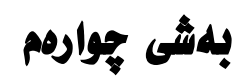

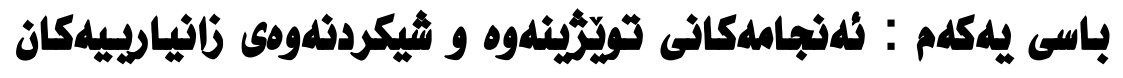

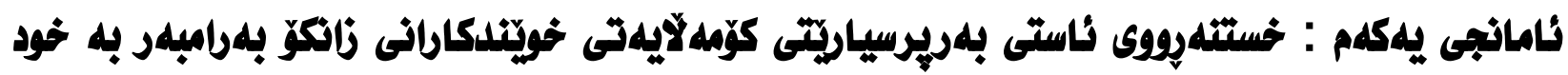

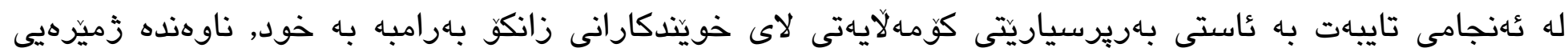

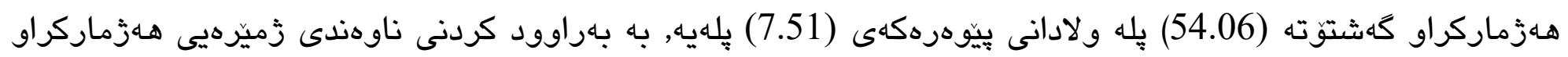

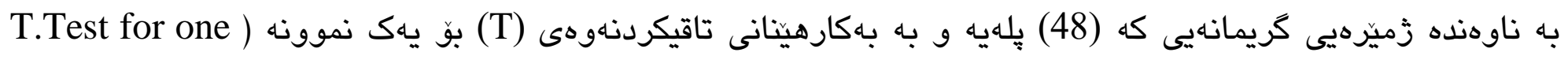

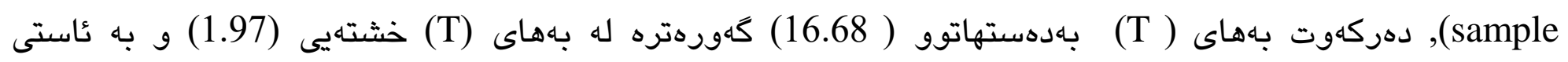

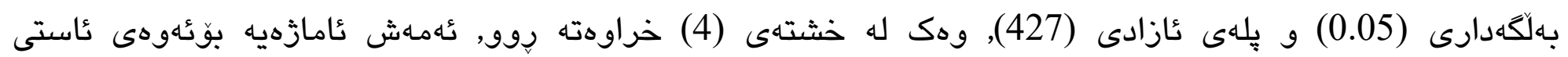

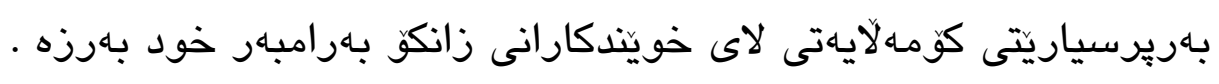


خشتهى (4) ثُاستى بهريرسياريتى كومالايهتى بهرامبهر به خود

\begin{tabular}{|c|c|c|c|c|c|c|c|c|}
\hline \multirow{2}{*}{$\begin{array}{l}\text { دهاستى } \\
\text { دهلهت } \\
\text { داست.05) }\end{array}$} & \multirow{2}{*}{ ئل ئهازى } & \multirow{2}{*}{ بألكاستى دي } & \multicolumn{2}{|c|}{ بههاى (T) } & \multirow{2}{*}{ يَّادهانى } & \multirow{2}{*}{ 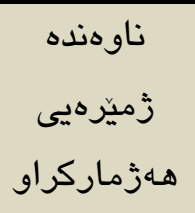 } & \multirow{2}{*}{ ثريميرهيى } & \multirow{2}{*}{ كَّريرسياريتيى } \\
\hline & & & خشتهيى & بهدهستهاتوو & & & & \\
\hline بهلكَهداره & 427 & 0.000 & 1.97 & 16.68 & 7.51 & 54.06 & 48 & دهرامبار خود \\
\hline
\end{tabular}

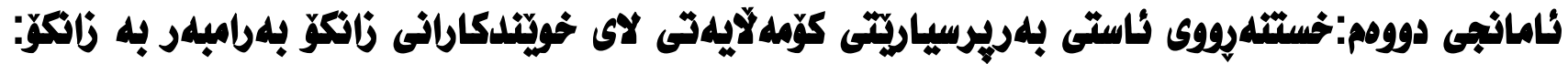

له ئهنجامى تايبهت به ئاستى بهريرسياريتّى كومهلاياهتى لاى خويتدكارانى زانكو بهرامبهر به زانكو, ناوهنده

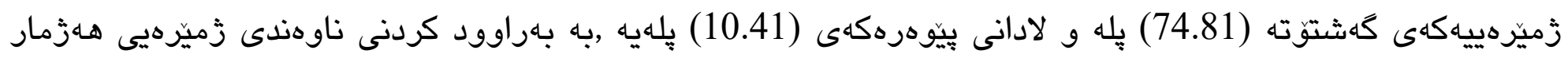

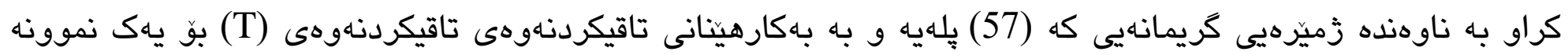
(T.Test for one sample)

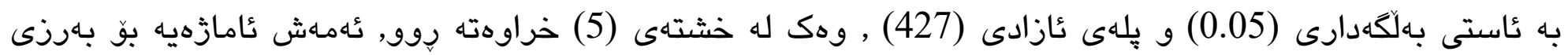

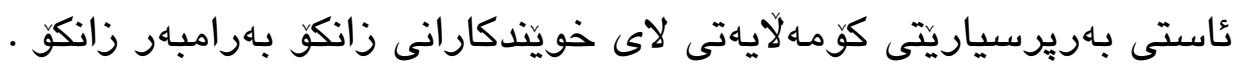

خشتهى (5) ناستى بهريرسياريتى كومهلايهتى بهرامبهر به زانكو

\begin{tabular}{|c|c|c|c|c|c|c|c|c|}
\hline \multirow{2}{*}{ 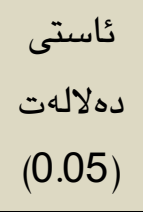 } & \multirow{2}{*}{ ئازادى } & \multirow{2}{*}{ بهلكَاستى } & \multicolumn{2}{|c|}{ به باى (T) } & \multirow{2}{*}{ بيّيوهرى لادانى } & \multirow{2}{*}{ هـاوهنديده } & \multirow{2}{*}{ ثريميّرهيى } & تهوهره \\
\hline & & & خشتهيى & بهدهستهاتوو & & & & كومه لآيايتى \\
\hline به لَكهداره & 427 & 0.000 & 1.97 & 35.39 & 10.41 & 74.81 & 57 & بهرامبهر زانكو \\
\hline
\end{tabular}

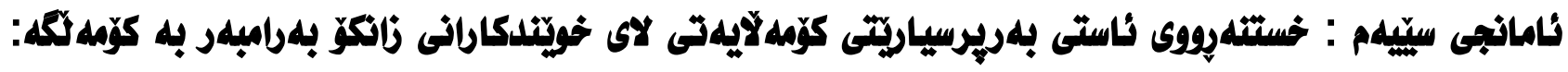

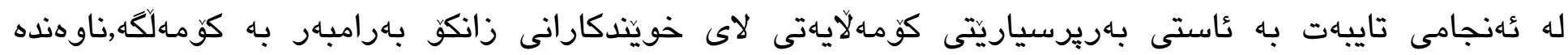

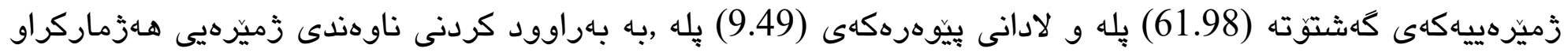

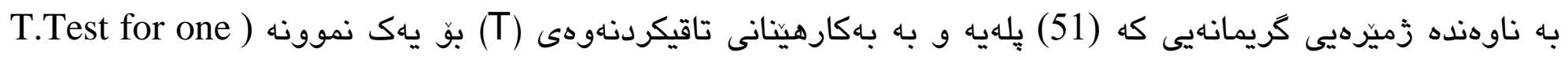

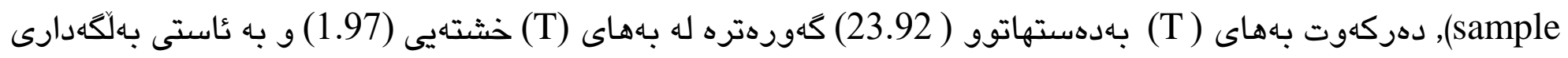




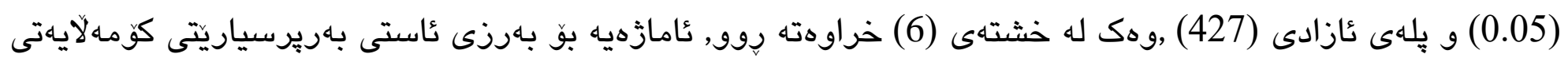
لاى خويندكارانى زانكو بهرامبهر كومهلكَّه .

خشتهى (6) عاستى بهريرسياريتى كومهلايهتى بهرامبهر به كومهلكه

\begin{tabular}{|c|c|c|c|c|c|c|c|c|}
\hline \multirow{2}{*}{ داسلالهت } & \multirow{2}{*}{ ئازادى } & \multirow{2}{*}{ بهلكَاستى } & \multicolumn{2}{|c|}{ بههاى (T) } & \multirow{2}{*}{ يَيْوهرى لادانى } & \multirow{2}{*}{ هـاوزميَرهيى } & \multirow{2}{*}{ ثريميرّهيى } & \multirow{2}{*}{ 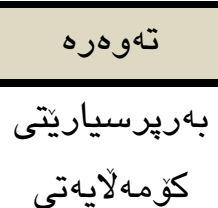 } \\
\hline & & & خشتهيى & بهدهستهاتوو & & & & \\
\hline بهلكَهداره & 427 & 0.000 & 1.97 & 23.92 & 9.49 & 61.98 & 51 & كؤمهالكَه \\
\hline
\end{tabular}

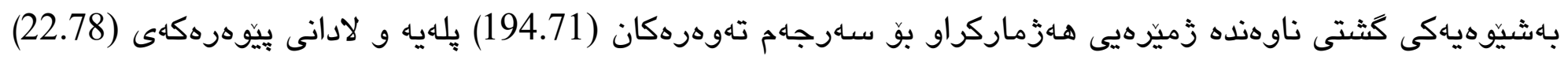

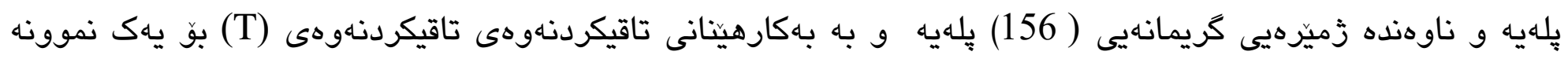
(T.Test for one sample)

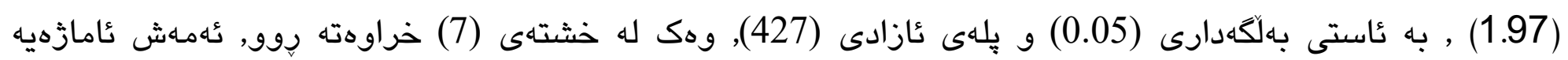

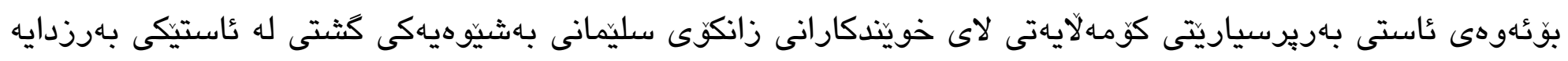

\section{خشتهى (7) عاستى بهريرسياريتى كومهلايهتى بهكشتى}

\begin{tabular}{|c|c|c|c|c|c|c|c|c|}
\hline \multirow{2}{*}{ 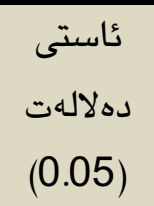 } & \multirow{2}{*}{ عَّازى } & \multirow{2}{*}{ بـاستى } & \multicolumn{2}{|c|}{ بههاى (T) } & \multirow{2}{*}{ بيّوهرى لادانى } & \multirow{2}{*}{ هـاوزيَّرديى } & \multirow{2}{*}{ 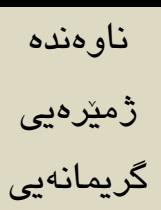 } & تهوهره \\
\hline & & & خشتهيى & باددستهاتوو & & & & باكُشتى \\
\hline بهلَّكهداره & 427 & 0.000 & 1.97 & 35.15 & 22.78 & 194.71 & 156 & \\
\hline
\end{tabular}

بهايِيى ئهو دهرئهنجامانه دهكهينه ئهوهى خويّندارانى زانكوى سليمانى كرنكى به بهرزكردنهوهى عاستى زانستى و

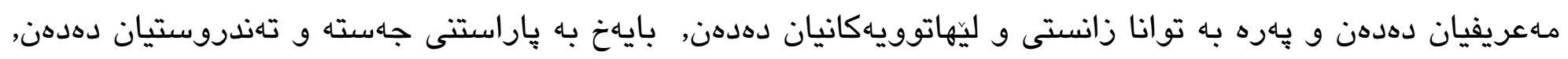

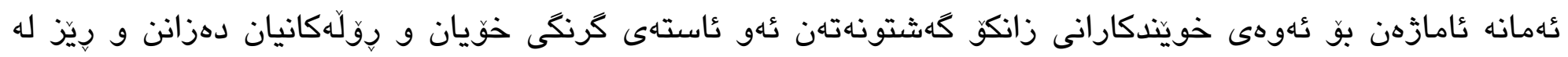

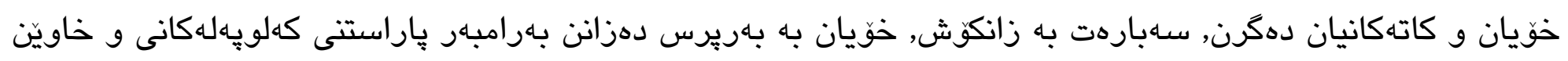

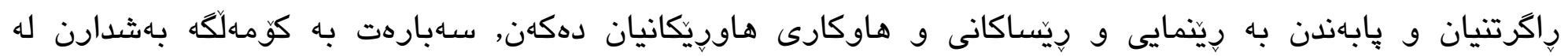




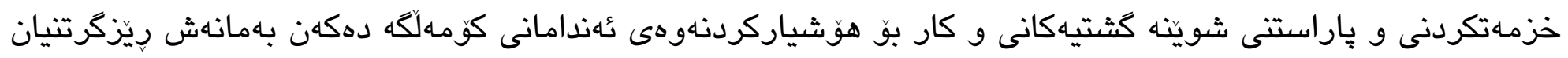

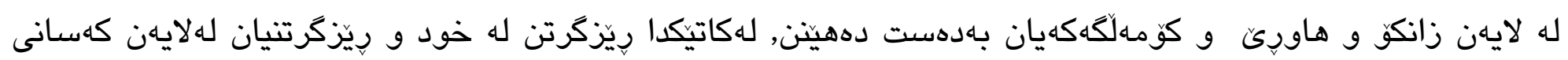

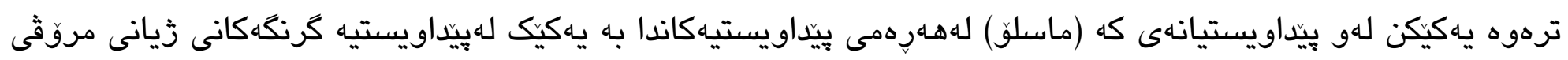

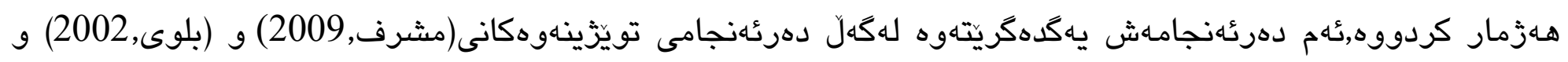

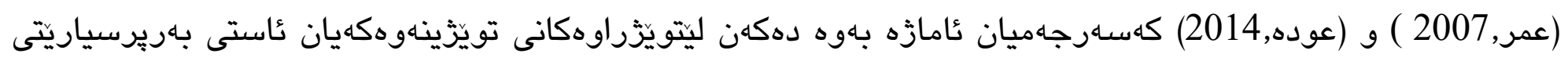

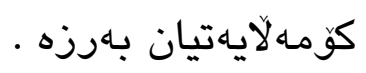

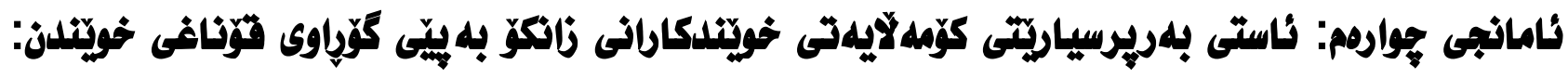

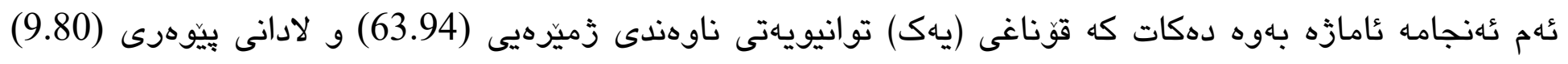

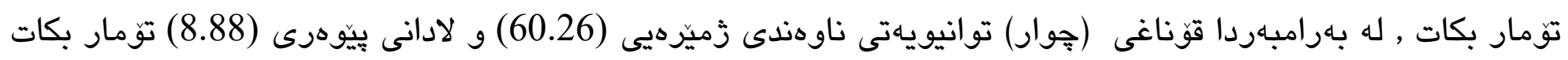

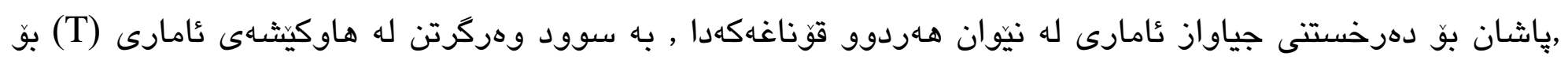

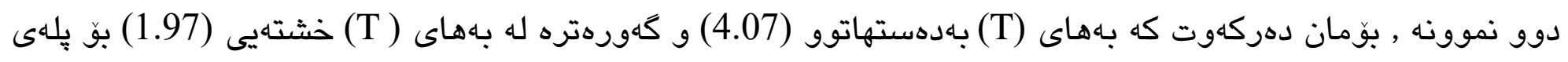

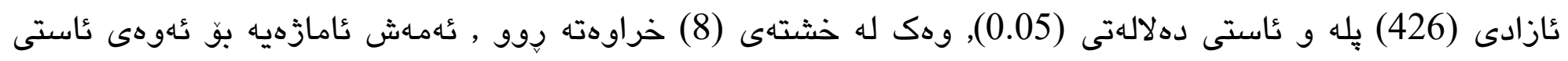

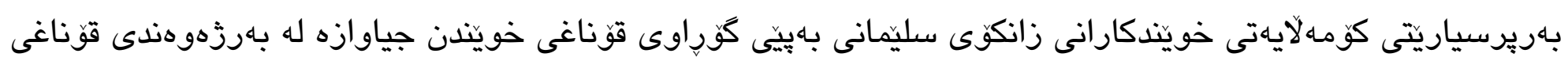
(ياك)

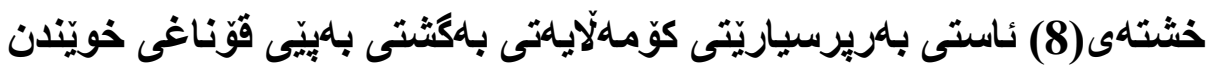

\begin{tabular}{|c|c|c|c|c|c|c|c|c|c|}
\hline \multirow{2}{*}{ 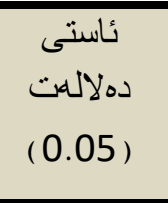 } & \multirow{2}{*}{ بألّاستهد } & \multicolumn{2}{|c|}{ به هاى (T) } & \multirow{2}{*}{ ئاز ادلى } & \multicolumn{2}{|c|}{ جو ار } & \multicolumn{2}{|c|}{ ياكى } & \multirow[b]{2}{*}{ تاهو هره } \\
\hline & & خشتهيى & بادذستهاتوو & & ليَّونى لادنى & زَمْيّر هيبى & 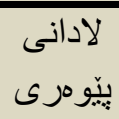 & زَّيّر هيى نـده & \\
\hline 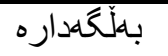 & 0.000 & 1.97 & 7.31 & 426 & 20.19 & 187.59 & 22.89 & 202.83 & باكگتشتى \\
\hline
\end{tabular}

كهوايه ئاستى بهريرسياريتى كوماهلايهتى لاع خويندكارانى قوناغى يهك بهرزتره له عاستى بهريرسيارينى كومههلايهتى

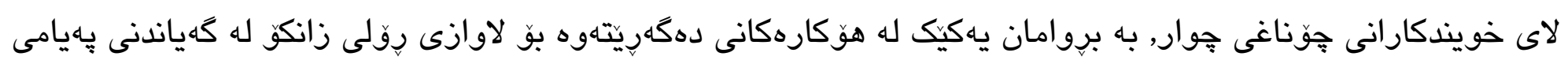

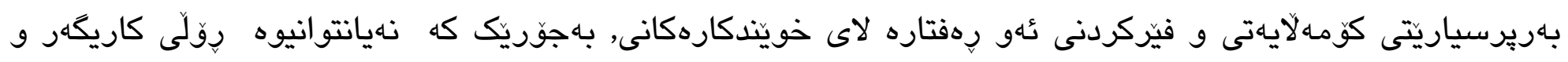

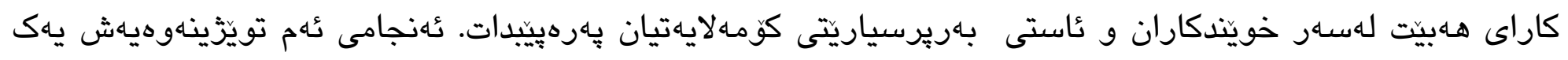

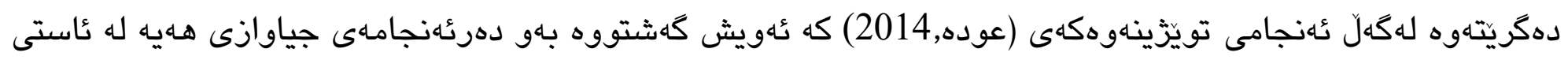

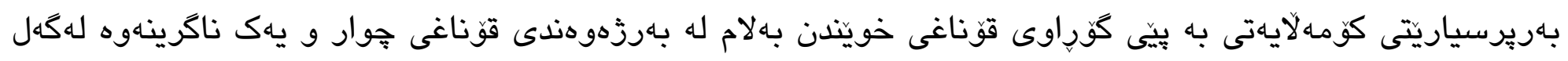


دهرئهنجامى تويَّينهوهكهى (بلوى ,2002) و(مشرف,2009) بهييّى دهئهامى تويَّزينهوهكهيان جياوازى نيه له

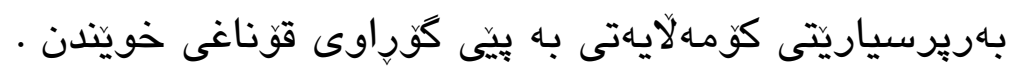

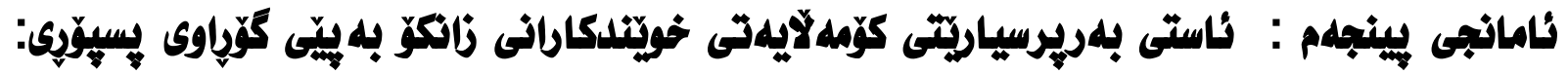

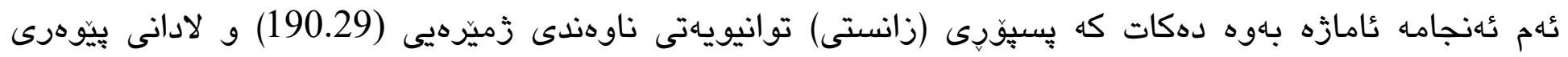

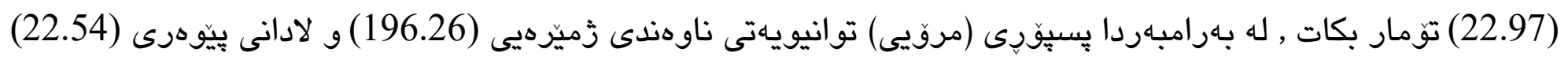

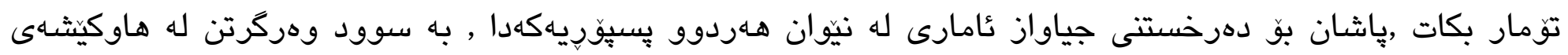

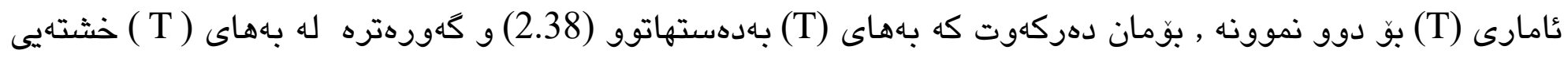

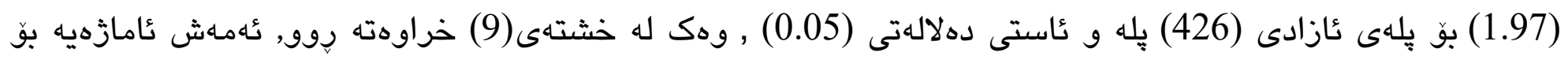

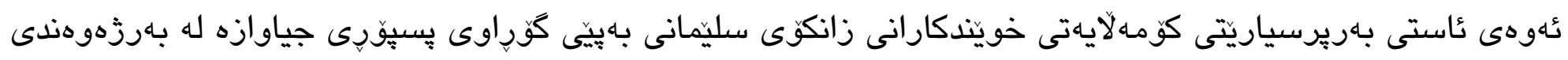

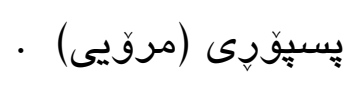

خشتهى (9) ناستى بهريرسياريّتى كومهلايهتى بهينى بسيّوريى

\begin{tabular}{|c|c|c|c|c|c|c|c|c|c|}
\hline \multirow{2}{*}{ د داسلهتى } & \multirow{2}{*}{ 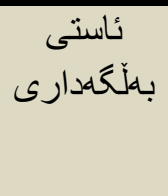 } & \multicolumn{2}{|c|}{ بهاى (T) } & \multirow{2}{*}{ ئزاز ادلى } & \multicolumn{2}{|c|}{ مروّيى } & \multicolumn{2}{|c|}{ زانستى } & \multirow[b]{2}{*}{ تنهو هره } \\
\hline & & خشتهايى & بمدهستهاتو & & لِيَّو هردى & زَّميّر هيى هنده & لايِو هرىى & نَّنَّ هنده & \\
\hline بـانلِكَهداره & 0.01 & 1.97 & 2.38 & 426 & 22.54 & 196.26 & 22.97 & 190.29 & باكگتنتى \\
\hline
\end{tabular}

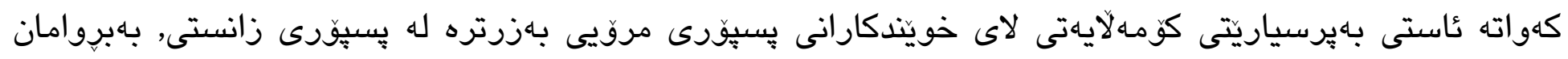

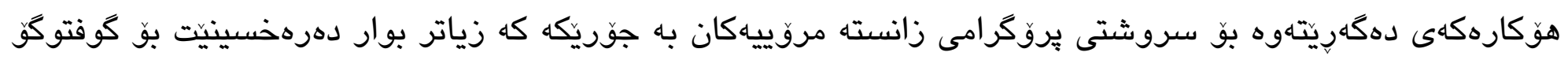

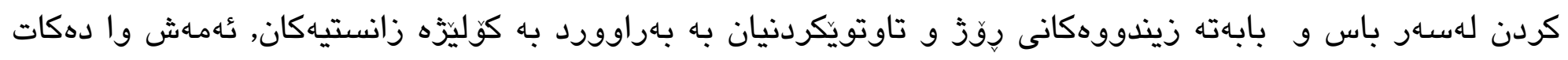

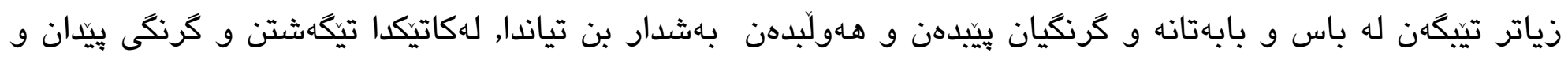

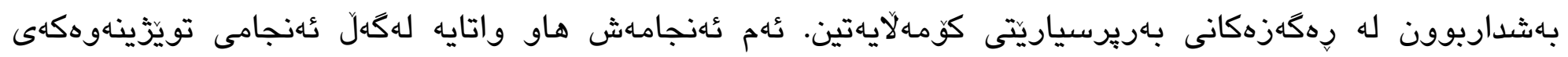

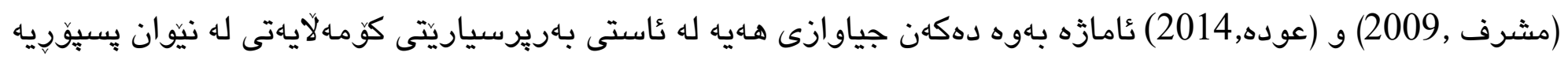

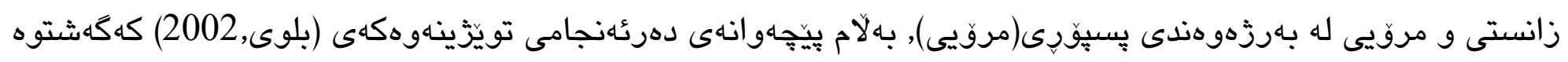

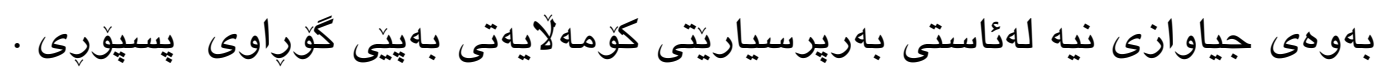


1. عاستى بهريرسياريتّى كومهلآيهتى لاى خويندكارانى زانكوى سليمانى بهرامبهر به خود بهرزه .

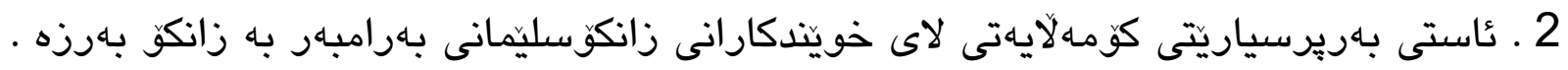

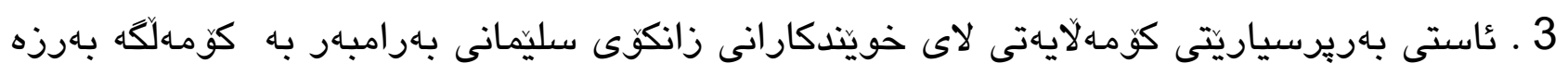

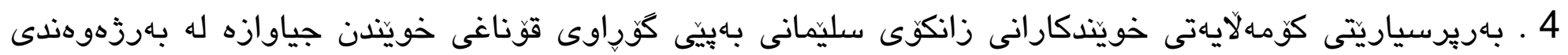
قوَناغى (يهك) .

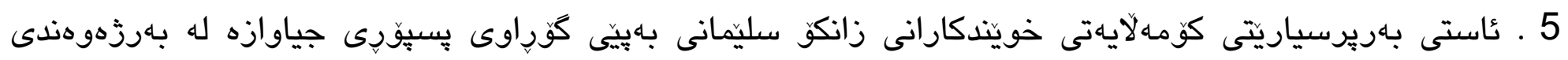

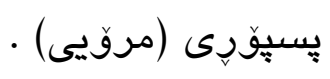

\section{دوومه : טإسياردمكان:}

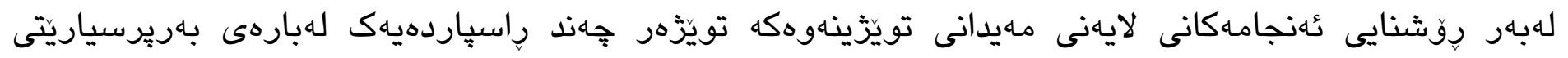

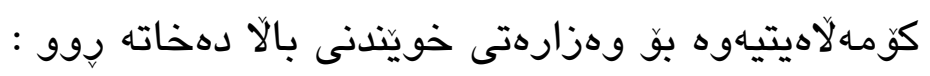

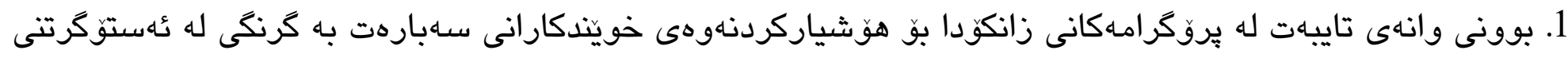

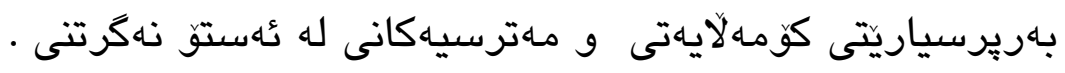

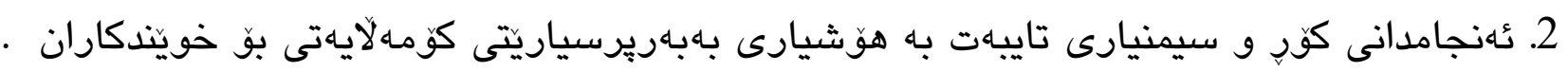

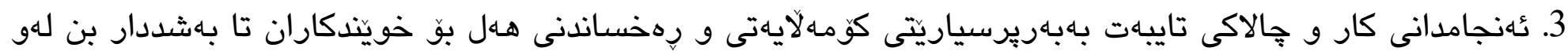

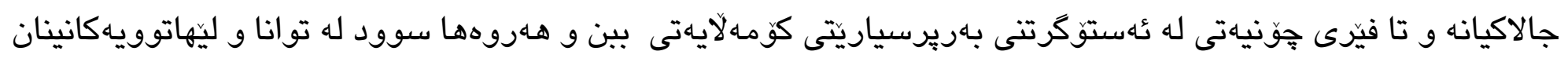
وهريكيريت

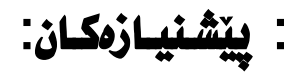

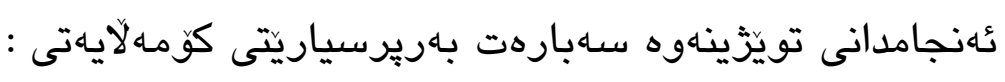

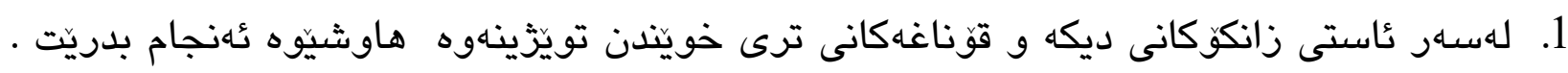

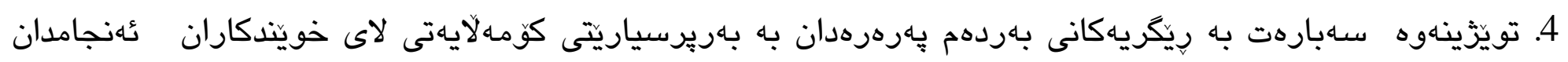

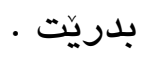

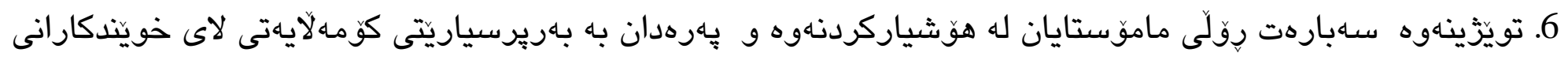

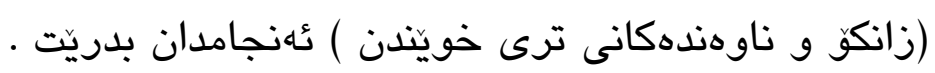




\title{
Social Responsibility in University Students
}

\section{Shno Hassan Abdulsamad}

Department of Sociology, College of Humanities, University of Sulaimani, Sulaimani, Kurdistan Region, Iraq.

E-mail: shnohassan56@gmail.com

\section{Paiman Abdulqadr Majeed}

Department of Sociology, College of Humanities, University of Sulaimani, Sulaimani, Kurdistan Region, Iraq.

E-mail: Paiman.majid@univsul.edu.iq

\begin{abstract}
:
Social responsibility takes an important role in constancy and tainquility of life in a society, tries to make the system of the society better and protects its roles, at the same time become a factor to perform each one's responsibility toward himself and the surrounding, and also make each individual mature, conscious in terms of rights, responsibilities, roles and comprehended ones about the social, political and general problems of the society and also encourages them to participate in resolving problems.

The researcher found it necessary to carry on such a study in order to investigate the level of social responsibility of the university students, and to underline the differences in the level according to variable,academic specialization,and study stages

The research population is all the bachelor students of first stage and forth stage of humanity and science academic specialization in the University of Sulaimani in the new camp in ( 2019 - 2020), but the sample of the study (428) students of the faculties of (College of Humanities, College of Law, College of Science, and College of Engineering )by the way of , the research is a kind of descriptive, and the adopted method is ( social survey), the researcher, for collection data, adopted scale to measure the social responsibility, and used some statistical means such as (coefficient alpha, person correlations coefficient, T, Test, means, standard deviation) The result indicates that the students of University of Sulaimani have a high level of social responsibility, and there are differences statistically concerning the variable of academic specialty ( science and humanity) in behalf of humanities, and of study stages ( first stage and forth stage ) in behalf of first stage .

These results were interpreted in the light of the literature review the researcher shed light on certain recommendations and suggestions .
\end{abstract}

Key words: Responsibility, Social Responsibility, University Students. 


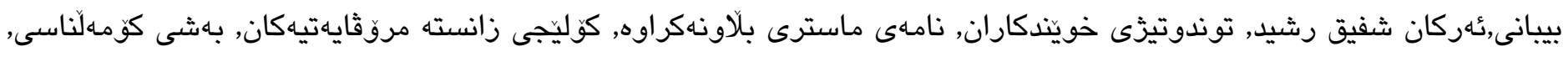
زانكوى سليمانى, 2017 .

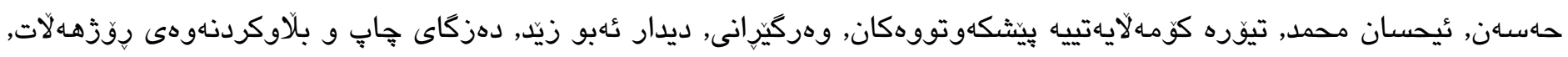
هـوليّز , 2016.

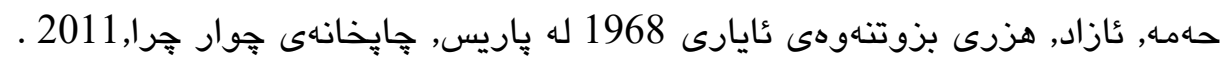

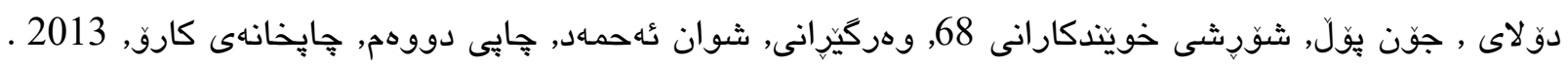

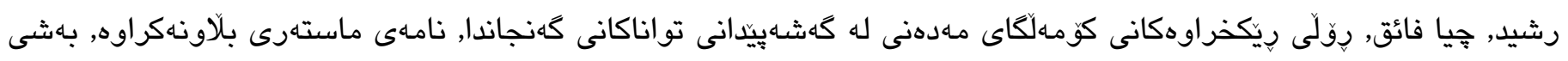

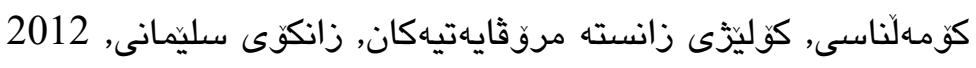
سديق, عارام ,كهنج و شوناس, جايهمانى كهنج, سليّمانى,2007.

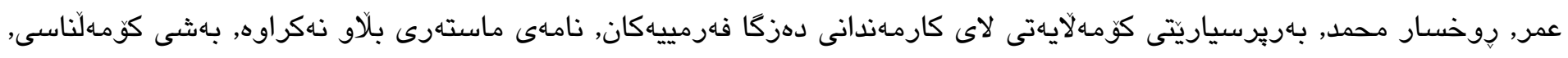

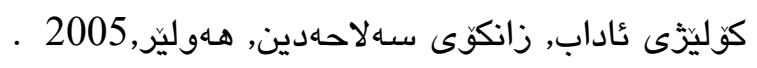

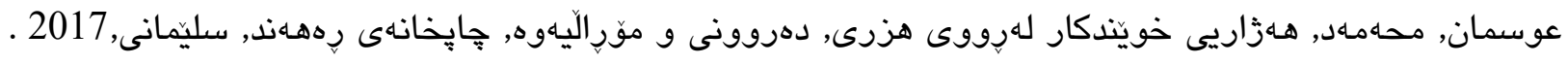
البلوى, محمد بن سليمان الفريعى, تشكل هوية الانا والمسئولية الاجتماعية لدى عينة من طلاب التخصصات والمستويات المختلفة, رسالة ماجستير غير منشورة,كلية

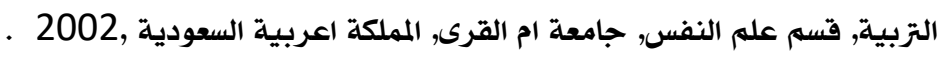
الحسن, احسان محمد, و عبدلحسين زينى, الاحصاء الاجتماعى, دار الكتب للطباعة و النشر, الموصل , 1982 . الصالح, مصلح احمد, الشامل قاموس مصطلحات العلوم الاجتماعية,ط1, دار عالم الكتب للطباعة والنشرو التوزيع, الرياض ,1999. العانى, نزار محمد سعيد, اضواء على الشخصية الانسانية, دار الشؤن الثقافية العامة ,1989 . خيرى,محمد, الاحصاء فى البحوث النفسية, دار الفكر العربى, القاهرة,1997 . شلتز, دوان نظريات الشخصية, ترجمة ,حمد دلى الكربولى, المكتبة الوطنية ببغداد ,1983 . 
عميرش, نجوى, الجامعيون بين القيم السائدة و القيم المتنحية, رسالة ماجستير غير منشورة, كلية العلوم الانسانية و الاجتماعية, قسم علم الاجتماع و الديموغرافيا ناوى زانكؤ, الجمهورية الجزائرية الديموقراطية الشعبية ,2005 .

فهمى ,محمد سيد المسئولية الاجتماعية, مكتب الجامعى الحديث, الاسكندرية, 2015 . فهيم ,كلير, طريق نجاح الشباب فى الحياة, مكتبة الانجلو الصرية للنشر, قاهرة ,2007 .

كرمة, صفاء طارق حبيب و نورجان عادل محمود دةمير, قوة الذكاء الاجتماعى فى تفعيل المسؤولية الاجتماعية و مفهوم الذات الاجتماعية, المكتب الجامعى الحلديث, 2014

مشرف, ميسون محمد عبدالقادر, التفكير الاخلاقى وعلاقته بالمسئولية الاجتماعية وبعض المتغيرات لدى طلبة الجامعة الاسلامية بغزة, رسالة ماجستير غير المنشورة , كلية التزبية,علم النفس الارشادى , الجامعة الاسلامية - غزة, 2009 .

مصطفى,شيلان عاكف, الاسلوب المعريفى (الاملى - الاندفاعى) و علاقته بالمسؤولية الاجتماعية لدى مديرى و مديرات المدارس الثانوية فى اقليم كوردستان - العراق , رسالة ماجستير غير منشورة, كلية التربية للعلوم الانسانية, علم النفس الزبوى جامعة صلاح الدين,اربيل , 2007.

عودة, ياسر على محمد المشاركة السياسية و علاقتها بالمؤلية الاجتماعية و تاثير الاقران لدى طلبة جامعة القدس المفتوحة, رسالة ماجستير غير منشورة, كلية التزبية, قسه علم النفس, جامعة الاسلامية - غزة ,2014 .

الحربى, ضيف الله ,قيم التزبوية الممارسة لدى طلبة جامعة المجمعة فى مملكة العربية السعودية مجلة الدولية الابحاث التربوية,مجلد 42,عدد 2, جامعة المجمعة-مملكة العربية السعوديـة,ابريل 2018.

الحسن, ابوبكر محمد , دور المؤسسة الاجتماعية فى تحسين اداء المنظمة,رسالة ماجستير غير منشورة, قسم علوم التسيير , كلية العلوم الاقتصادية والتجارية و علوم التسيير , جامعة محمد خيضر - بسكرة-, الجزائر ,2014 .

الخمسان, محمد سليمان سالم, تأثير القيم الاجتماعية للعمالة الوافدة على الأمن الاجتماعي بالمجتمع السعودي, رسالة ماجستير غير منشورة,كلية الآداب ,قسم الاجتماع, جامعة القاهرة ,2012.

الزيناتى, اسامة محمد خليل, دور اخلاقيات المهنة فى تعزيز المسئولية الاجتماعية فى المستشفيات الحكومية الفلسطينية رسالة الماجستير غير منشورة فى برنامج القيادة والادارة,جامعة الاقصى ,2014 .

الشاعر, منار محمود, الضغوط النفسية والمسئولية الاجتماعية لدى ضباط اسعاف حرب غزة فى ضوء بعض المتغيرات, ررسالة ماجستير غير منشورة, كلية تربية,قسم علم النفس,جامعة الاسلامية-غزة,1 2011 . 


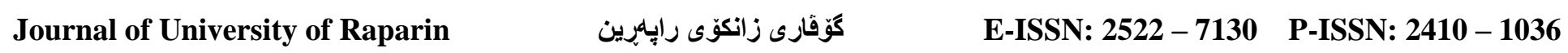

الهذلىنائف بن سراج النجيبى ,الاتجاه نحو ظاهرة الارهابررسالة ماجستير غير منشورة,قسم علم النفس,كلية التربية,جامعة ام القرى المملكة العربية السعودية, 2009

بو شعيرة, خاليد محمدرالاغتراب فى النسق التعليمى لدى الشباب الجامعى فى ضوء بعض المتغيرات: دراسة حالة ميدانية على عينة من طالة كلية التربية, مجلة علوم

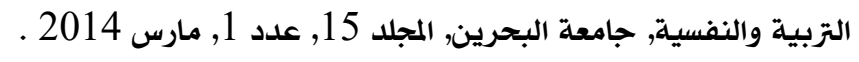

حسونة ,باس فريز, المسئولية الاجتماعية و الضغوط النفسية لدى الثيادات الطلابية فى جامعة القدس امفتوحة, رسالة ماجستير غير منشورة, قسم علم النفس, كلية التزبية, جامعة الاسلامية, غزة , 2014 .

حليمة, قادرى, اتجاهات الشباب نحو المسئولية الاجتماعية, مجلة علوم النفسية والتعليمية, جامعة وهران 2, الجزائر,2019

رشيد, بوتقرابت,ظاهرة الاهتمام بالباس عند الشباب الجامعى ,رسالة ماجستير غير منشورة, قسم علم الاجتماع , كلية العلوم الاجتماعية و الانسانية, جامعة الجزائر .2007,

طلحى, خولة, السؤلية الاجتماعية للقطاع الخاص فى الجزائر, رسالة ماجستير غير منشورة, كلية الحقوق والعلوم السياسية, قسم العلوم السياسة, جامعة العربى بن مهيدى- ام البواقى ,2015.

قاسم , جميل محمد, فعالية برنامج ارشادى لتنمية المسئولية الاجتماعية لدى طلاب المرحلة الثانوية, رسالة ماجستير غير منشورة, كلية التربية, علم النفس- الارشادى, الجامعة الاسلامية - غزة ,2008.

Berl, Robert L. Nicholas C. Williamson and Terry Powell, A Critique and Test of Maslow Hierarchy of Need, The Journal of Personal Selling and Sales Management, Vol.4 , No.1, May 1984.

Cohen,Louis, Lawrence Manion \& Keith Morrison, Research Methods in Education, 6th edition, Routledge Taylor and Francis Group press, New York \& London, 2007.

The basic practice of statistics, 6th ed., W. H. Freeman and Company press, New York, 2013, Diana,Mindrila Neuman, W. Lawrence, Social Researcher Methods: Qualitative and Quantitative Approaches, 7th edition, British Library Cataloguing-in-Publication Data press, England, 2014 .

Growth in Human Motivation: Beyond Maslow, Indian Journal of Industrial Sengupta , Sunita Singh, Relation,Vol.47,No.1, Shri Ram Centre press, 2011.

The American Taormina, Robert J and Jennifer H. Gao, Maslow and Motivation Hierarchy: Measuring of the needs, Journal of Psychology ,Vol. 126,No.2, Uneversty of Illinois Press, 2013 


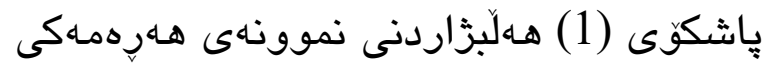

\begin{tabular}{|c|c|c|c|}
\hline نموونه & كومَمهلكَه & نموونه & كومـلكَه \\
\hline 314 & 1200 & 28 & 30 \\
\hline 321 & 1300 & 45 & 50 \\
\hline 326 & 1400 & 64 & 75 \\
\hline 331 & 1500 & 81 & 100 \\
\hline 351 & 2000 & 94 & 120 \\
\hline 364 & 2500 & 111 & 150 \\
\hline 392 & 500 & 136 & 200 \\
\hline 403 & 7500 & 157 & 250 \\
\hline 408 & 1000 & 176 & 300 \\
\hline 417 & 20000 & 192 & 350 \\
\hline 419 & 30000 & 206 & 400 \\
\hline 421 & 40000 & 219 & 450 \\
\hline 422 & 50000 & 230 & 500 \\
\hline 424 & 100000 & 259 & 600 \\
\hline 424 & 150000 & 257 & 650 \\
\hline 424 & 20000 & 265 & 700 \\
\hline 425 & 250000 & 278 & 800 \\
\hline 425 & 500000 & 289 & 900 \\
\hline \multirow[t]{2}{*}{425} & 1000000 & 298 & 1000 \\
\hline & & 307 & 1100 \\
\hline
\end{tabular}




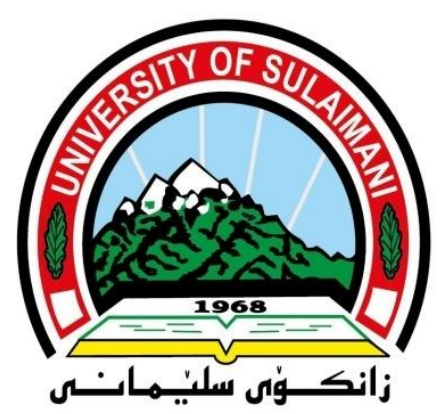

يَاشكوّى (2) فُورِمى يِيَوانه

وهزاردتى خويّندنى بالاً و تويَّرينهوهى زانستى زانكوّى سليّمانى / كوّليُّرى زانسته مروّقايهتيهكان

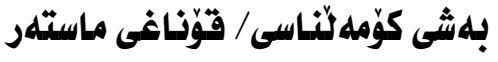

خويَّندكارى بلهريّز :

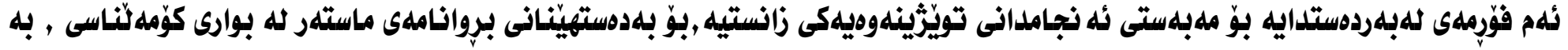

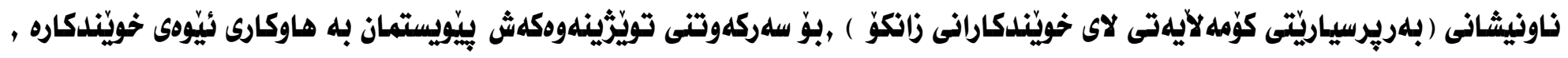

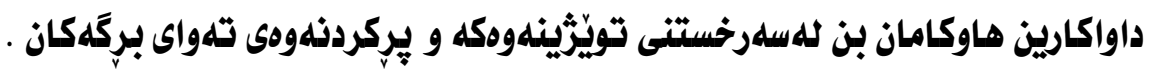

خويّندكارى ماستهر

شنوّ حسن عبدالصمد
بله بهريهرشتى

ي.ى.د. يُه يمان عبدالقادر مهجيد 
يلهكم : زانياريه تايبهتيهكان :

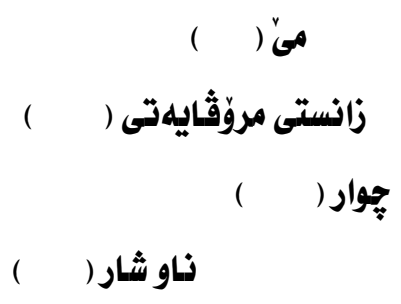

7 7. تهوهرهى يهكلم : بلهريرسياريّتى كوّههلاليهتى بلهرامبهر به خود

\begin{tabular}{|c|c|c|c|c|c|c|}
\hline زوّر للهَّلَّيدا & لمكَّليدا نيه & 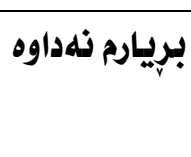 & لمكَّليدام & 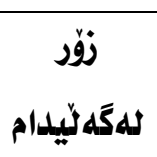 & 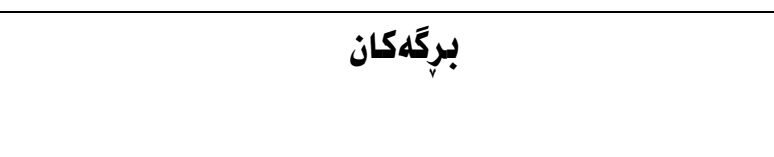 & $\dot{j}$ \\
\hline & & & & & 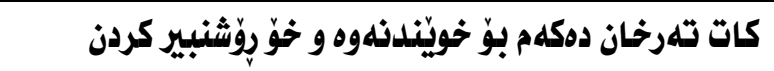 & 1 \\
\hline & & & & & 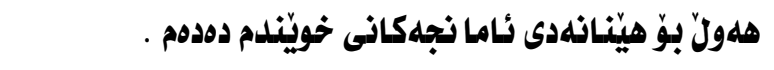 & 2 \\
\hline & & & & & هوشيارم بلهرامبلهر مافهكانم . & 3 \\
\hline & & & & & 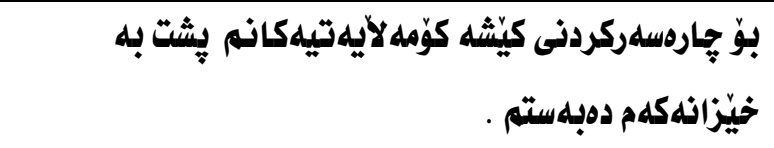 & $\underline{4}$ \\
\hline & & & & & 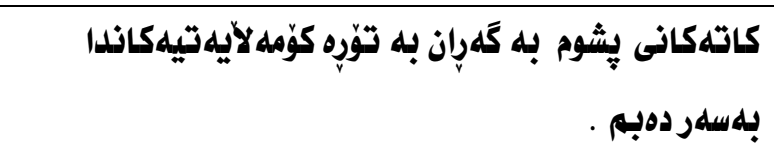 & $\underline{5}$ \\
\hline & & & & & 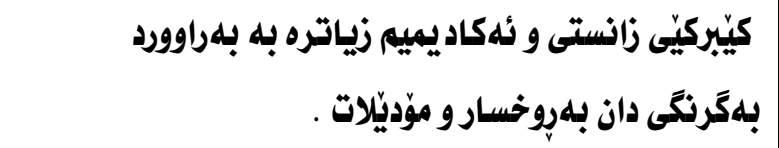 & 6 \\
\hline & & & & & بى" هيوام لهداهاتووى خويّندندكلهم . & $\underline{7}$ \\
\hline & & & & & 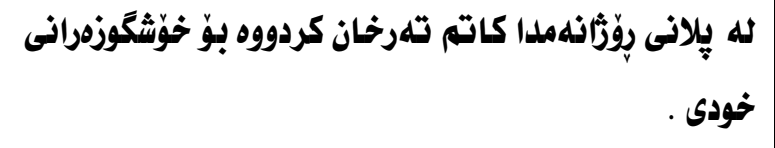 & 8 \\
\hline & & & & & 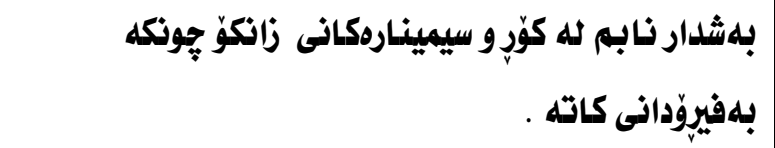 & $\underline{9}$ \\
\hline & & & & & 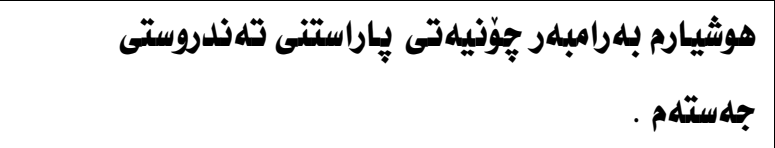 & 10 \\
\hline & & & & & 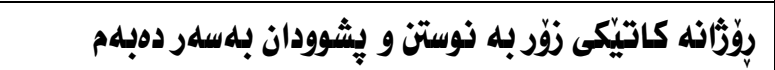 & $\underline{11}$ \\
\hline & & & & & 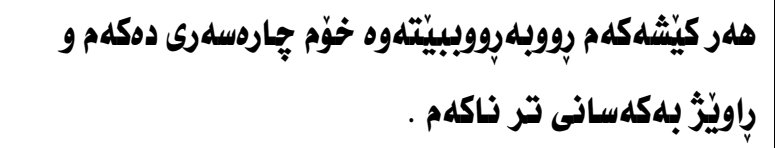 & 12 \\
\hline & & & & & هوشيارم بهرامبهر ئهركهكانم ومك خويّندكاريّك له زانكوّ & 13 \\
\hline
\end{tabular}




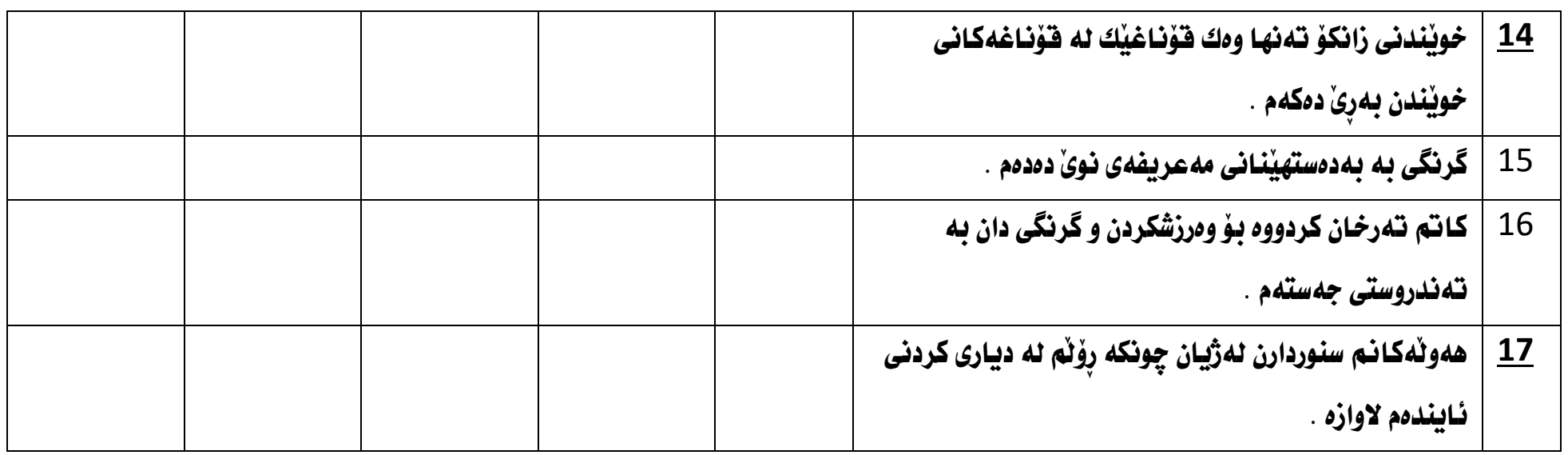

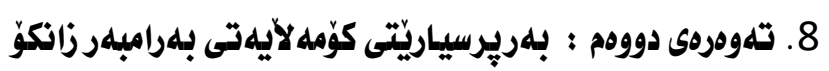

\begin{tabular}{|c|c|c|c|c|c|c|}
\hline هيج لهكَليدا & لمَكَلِيليدا نيه & 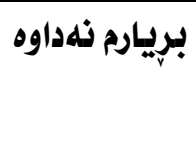 & 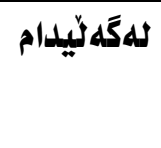 & 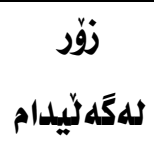 & بركَكان & $\dot{j}$ \\
\hline & & & & & 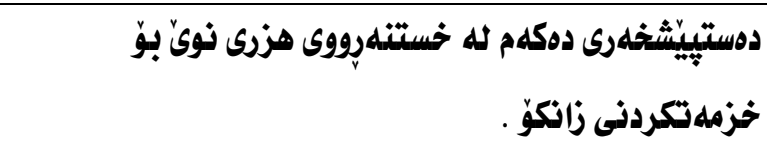 & 1 \\
\hline & & & & & 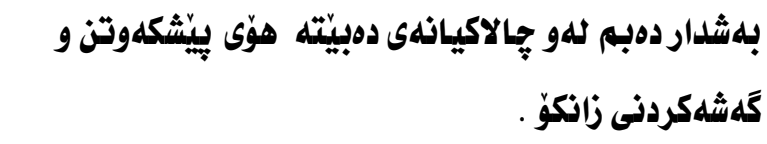 & 2 \\
\hline & & & & & هاوكارى هاوريّكانم دهكهم له كاتى يِيَويستلا . & 3 \\
\hline & & & & & 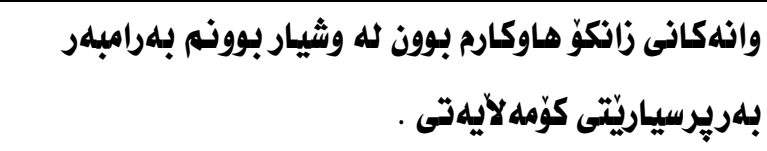 & 4 \\
\hline & & & & & 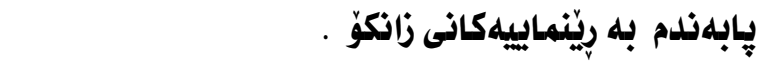 & 5 \\
\hline & & & & & ئامادهى وانهكانم روّرَانه لهكاتى خوَيلـا . & 6 \\
\hline & & & & & 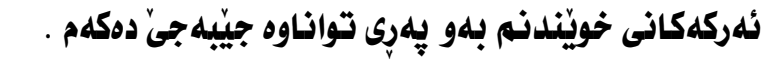 & 7 \\
\hline & & & & & كتيّيخخانهكانى زانكوّ بلهسوودن بوَّم له كوّكردنهوهى زانيارى & 8 \\
\hline & & & & & ياساكانى تاقيكردنهوهم لا يلهسند نيه . & $\underline{9}$ \\
\hline & & & & & 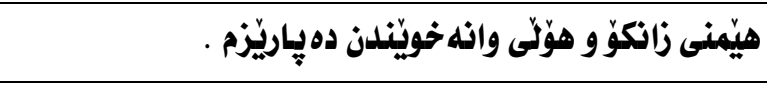 & 10 \\
\hline & & & & & مافهكانم وهك خويّتدكاريّك له زانكوّدا پِاريّرزاوه . & 11 \\
\hline
\end{tabular}




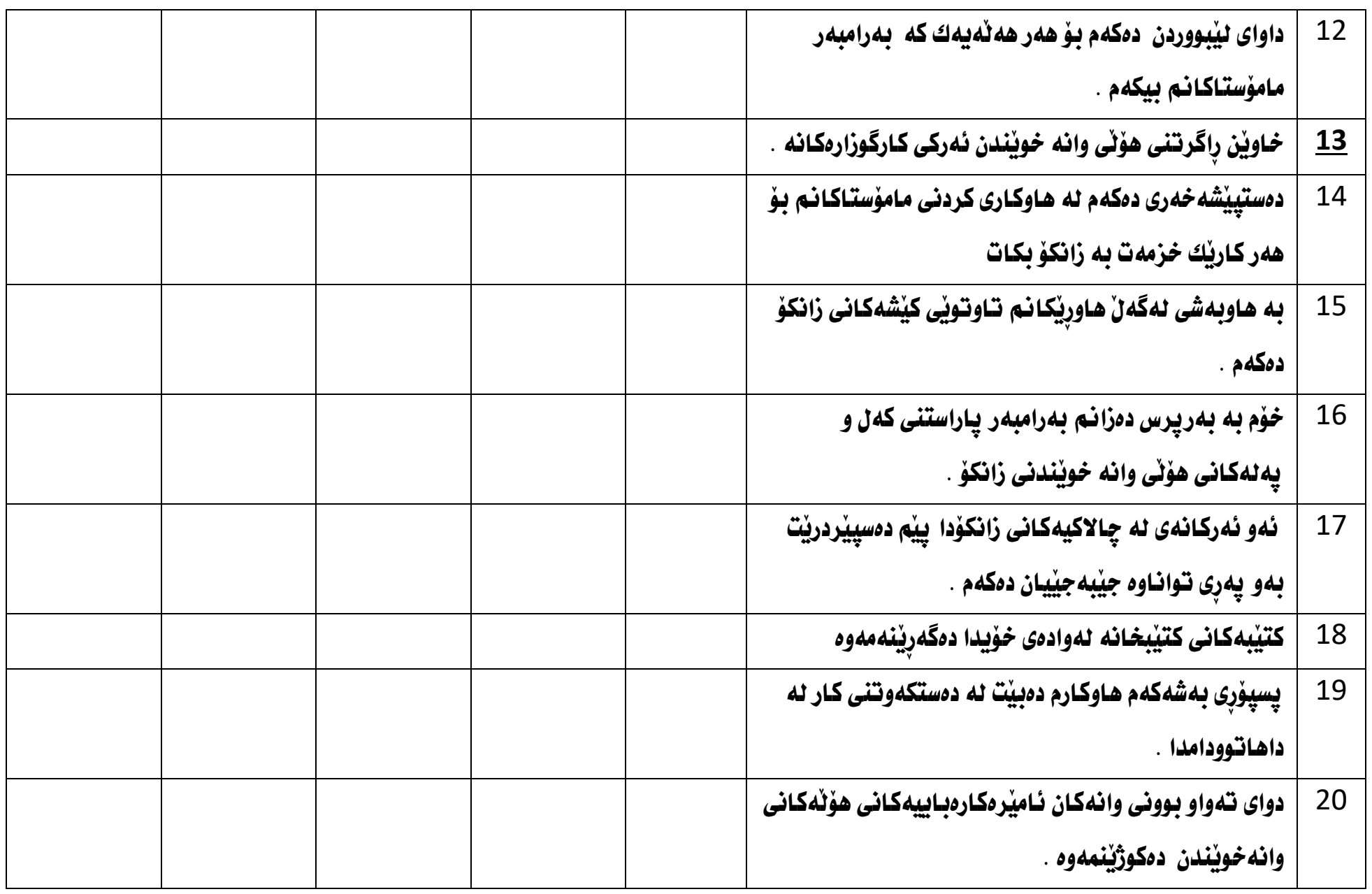

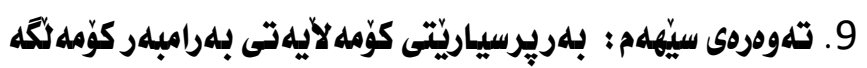

\begin{tabular}{|c|c|c|c|c|c|c|}
\hline هيج للهَّليدا & لهَّهليّليدا نيه & بريارم نهداوه & لهَكَلَيدام & 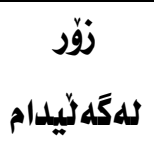 & برَّكَكان ] & $\dot{j}$ \\
\hline & & & & & 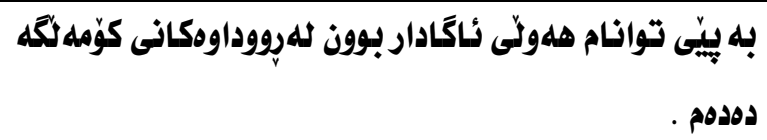 & 1 \\
\hline & & & & & 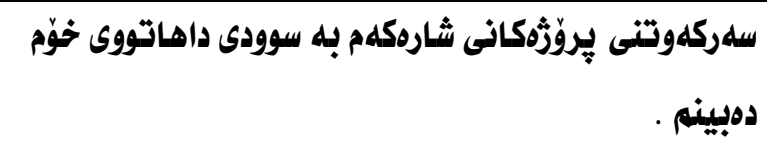 & 2 \\
\hline & & & & & 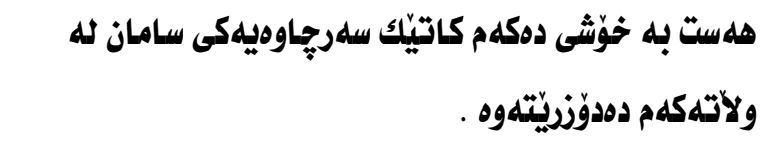 & 3 \\
\hline & & & & & 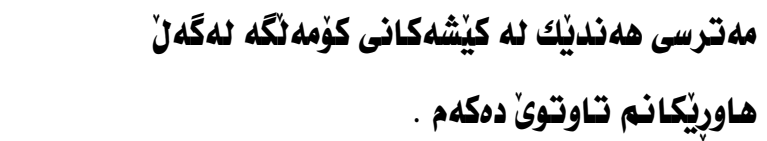 & 4 \\
\hline
\end{tabular}




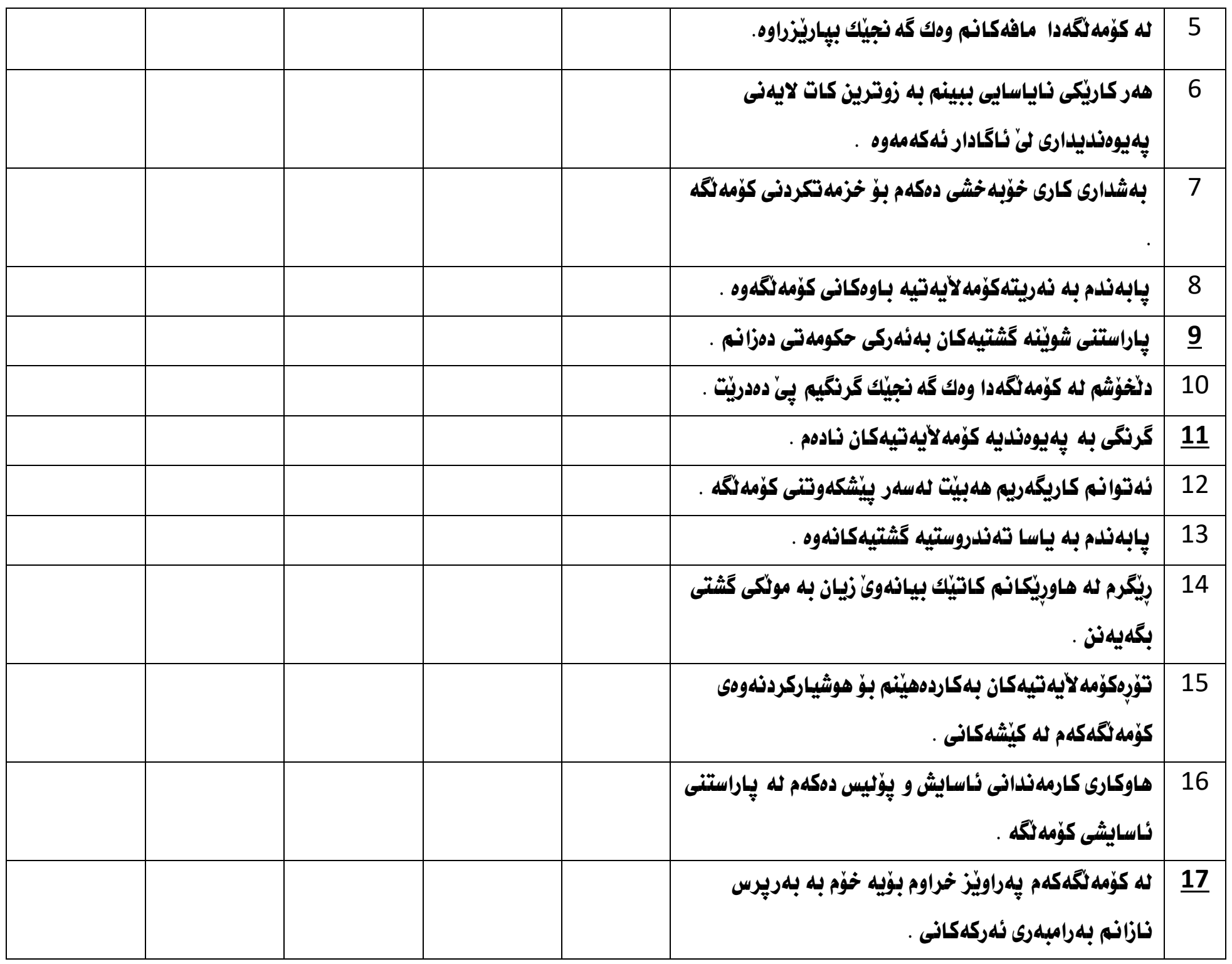




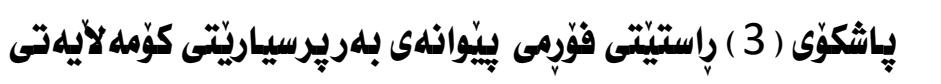

\begin{tabular}{|c|c|c|c|c|c|c|c|}
\hline لَّلَّيَّهى & ثرئهارهى يֶرسيارى & زيهارهى يرسيارى & يُوّتَ & 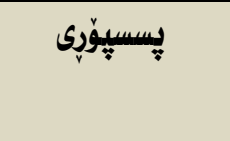 & يلهى زانستى & ناوى يسيوزّران & $\dot{j}$ \\
\hline$\% 88.88$ & 6 & 48 & نيه & كوّمهلَّناسى & يِروَفيسور & د. ئاسوّ ابراهيم عبدلله & 1 \\
\hline$\% 94.44$ & 3 & 51 & سلهروّكى بلهُ & يهروروردزدانى & يِروّفيسوّر & د. صابر بكر مصطفى & 2 \\
\hline$\% 100$ & نيه & 54 & ياريدهدهرى رِآَر & يل دهرونزانى & يَروّفيسورى & د. حسن فخرالدين خالد & 3 \\
\hline$\% 96.29$ & 2 & 52 & نيه & كوّمه لاليهذتى & يِروَفيسوَرى & د. دراد حكيي & 4 \\
\hline$\% 94.44$ & $3 \square$ & 51 & | & 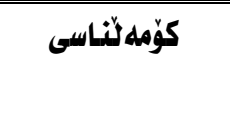 & 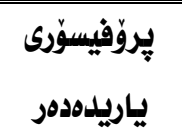 & 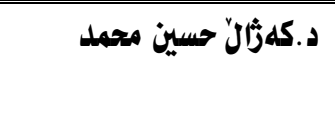 & 5 \\
\hline$\% 98.14$ & 1 & 53 & نيه & كوّمهل'ناسى & يَروّفيسوَرى & د. نجاة محمد فرج & 6 \\
\hline$\% 90.74$ & 5 & 49 & سلهروّك بلهى & كارى كوّمهلاليهتى & يِروَفيسوَرى & د. دزخَار مصطفى غفور & 7 \\
\hline$\% 98.14$ & 1 & 53 & 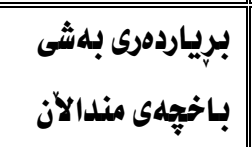 & يلي درووونتاسى & يـاروّويسوَرى & د.عبدالصمد احمد محمد & 8 \\
\hline$\% 94.44$ & 3 & 51 & نيه & 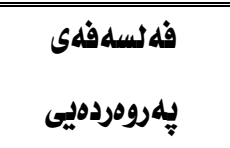 & يـروَفيسوَرى & د.نيان نامق صابر & 9 \\
\hline$\% 100$ & نيه & 54 & نيه & كارى كوَّهه لآيهتى & يـروّفيسوَرى & د. كوردستان عمر محمد & 10 \\
\hline$\% 98.14$ & 1 & 53 & 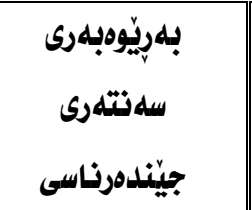 & دروستى دهرووذى & ماموَستا & د. هلناو حسن محمد خان & 11 \\
\hline$\% 100$ & لــيه & 54 & لـيه & 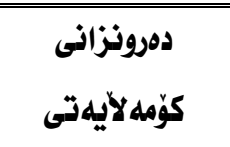 & لـــمامؤستا & |مام. خوّشى لطيف طه & 12 \\
\hline$\% 96.14$ & 25 & 623 & \multicolumn{5}{|c|}{ كوّى كَشتى } \\
\hline
\end{tabular}

